\title{
Government's Catalytic Role in Emerging Economy: Critical Comparison of China's Conspicuous Strength in Wind and Solar Industry
}

\author{
Narasimalu Srikanth \\ National University of Singapore, Singapore \\ Chihiro Watanabe \\ Tokyo Seitoku University, Japan
}

\begin{abstract}
In light of a conspicuous strength in China's solar and wind industry in recent years this paper analyses the catalytic role of the government in inducing the institutional source of its strength. Critical comparison of the two industries show China's renewable energy policies for wind industry was more effective than the solar industry through adopting a self-propagating functionality development through fusing the external technology with domestic industries know-how to co-evolve both production and diffusion through effective assimilation. This suggests a new insight for growing economy to devise effective policy framework to develop a globally competitive industry.
\end{abstract}

Keywords: Fusion, learning, global best practices, growing economy, global competitiveness.

\section{INTRODUCTION}

The policies of the Government of China (GOC) have been praised by the world community including the Europe and USA, mainly the implications of the twelfth five year plan for the global race towards low carbon technology competiveness. (Worldbank, 2013; IEA, 2013; REN21, 2010, Wharton, 2011). For example, after the renewable energy law was passed in 2005 (NREL, 2009), the uptake has been significant as shown in Figure 1 and the total adoption of wind energy has reached $66 \mathrm{GW}$ by 2011. This has been supported by conspicuous domestic production capacity that has been moving towards indigenized with least import of components. This was achieved through Chinese government's catalytic role in inducing stimulation through right policies such as renewable energy law in 2005 and setting sincere targets such as $15 \%$ renewables by 2015 (APERC, 2009). For example in wind energy it is focused to achieve at least $100 \mathrm{GW}$ of wind energy by 2015 (Reuters, 2013) and with its accelerated pace it may reach the target much earlier.

Journal of Technology

Management for Growing Economies

Vol. 4 No. 1

April 2013

pp. $7-48$

\section{ChItKARA 司 \\ UNIVERSITY}

C 2013 by Chitkara University. All Rights Reserved. 
Srikanth, N.

Watanabe, C.

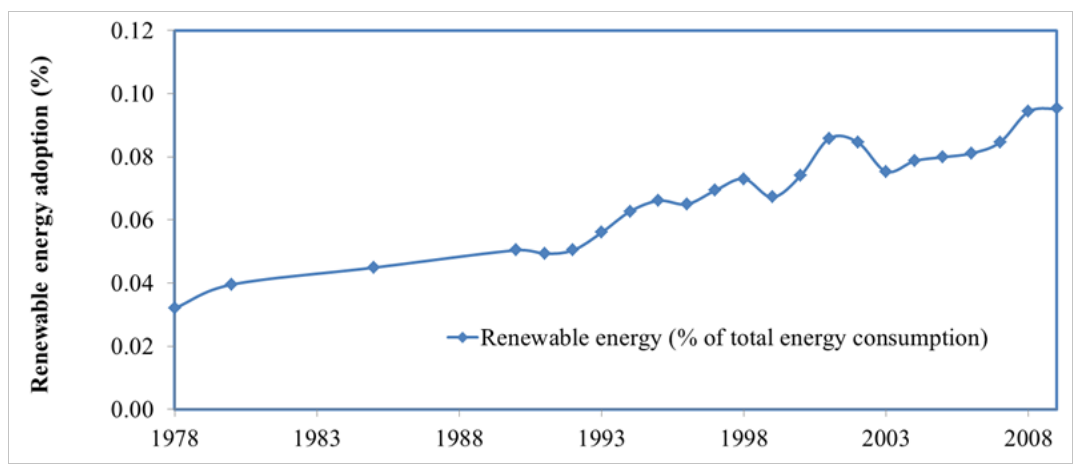

Figure 1: Renewable energy adoption in China (1979-2009).

What interests the research community is the understanding of the underlying mechanisms and working methods behind the catalytic role of government in achieving such goals as those of an emerging nation compared to its policies in year 2000 (Sinton and Frindley, 2000). This forms the focus of this research. One observation is that China has setup a virtuous cycle between assimilation capacity increase and acceleration in the emergence of the functionality development (Watanabe, et al. 2003). Since the opening of its domestic market in the 1980s, China has been constantly investing in its research and development upto $2 \%$ of the GDP (ERI, 2009 and Buijs, 2011). This has helped in the growth of industrial enterprises, research institutes and higher educational institutes. Such institutes have been planned as clusters over the years due to which, today China has more than 100 clusters spread across its 41 provinces with over 500 production centres, 30 university technology parks and 20 business foundation parks, etc. (Frost, 2010) that contributes to significant manufacturing output at various levels viz., light, medium and heavy industry output as shown in Figures 2 and 3.

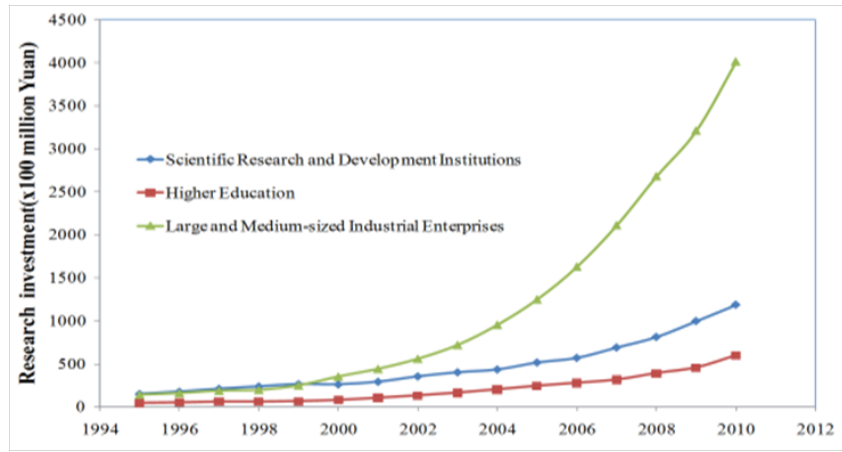

Figure 2: Growth of education and research institutions and industrial enterprises in China (1995-2010).

Journal of Technology Management for Growing Economies, Volume 4, Number 1, April 2013 


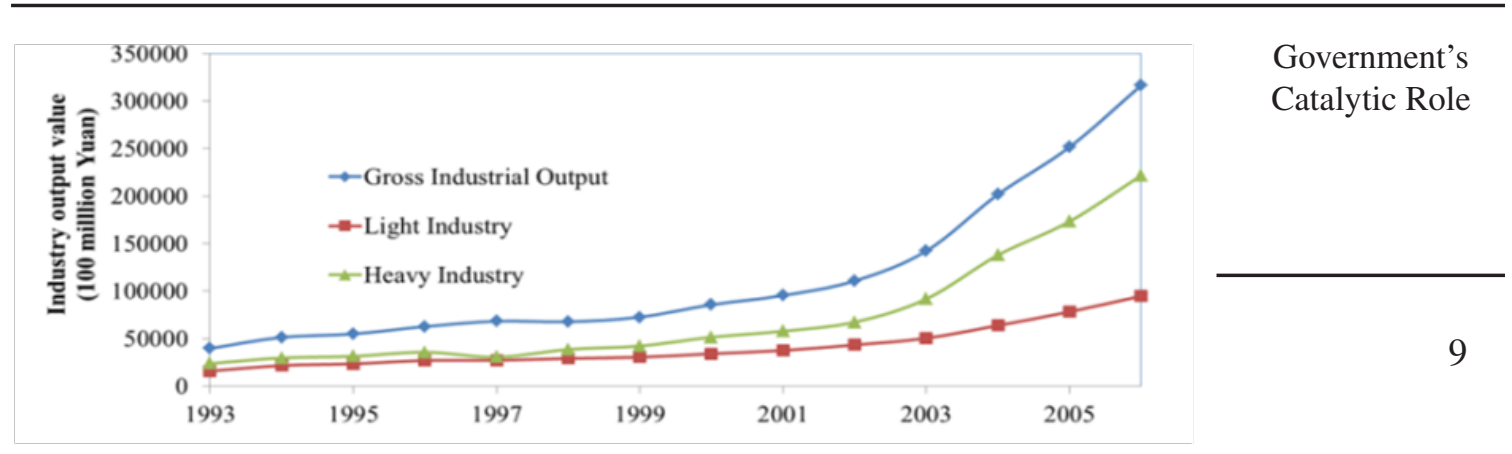

Figure 3. Growth of education and research institutions and industrial enterprises in China (1993-2006).

Foregoing observation prompts us that China's recent renewable energy initiatives (Bogaert, 2010; NREL, 2013) can largely be attributed to its conspicuous accomplishment in its renewable energy which are as follows:

1. Renewable energy law in 2005 ,

2. Higher target of $15 \%$ renewable energy by 2015 ,

3. Insist on $90 \%$ domestic parts,

4. Support formation and navigate goals of industrial clusters, and

5. Setting up a consortia between academia and industries.

Such stimulants have helped to induce its industrial clusters towards assimilation of knowledge spillover from earlier foreign direct investment (FDI). In addition, China has analysed relevance of earlier domestic innovations developed for other industries, which have transformed towards new industry needs. Partly these skill sets lie with the skilled labour trained in earlier industries with similar technologies. The result of such assimilation is useful in increasing the acceleration of production such that emergence of new functionality development is observed. In the case of China's wind industry, such functionality development has been observed in terms of size of the wind turbines growing in geometric size as a consequence of sophisticated design, increased production and installation ability that has reached to the top level in the world.

Similar observation with China's solar industry confirms the earlier study on fusing behaviour of the domestic firms with their know-how along with global free open access information such as patents and design standards in solar cell and module Photovoltaic (PV) manufacturing, due to knowledge spillover from relevant industries such as semiconductor and integrated circuit manufacturing industries (Srikanth and Watanabe, 2012). Moreover, estimates 
Srikanth, N.

Watanabe, C. confirm that China has healthy solar natural resources as discussed in further section. However, in terms of installations, China has failed in adopting solar PV as a significant energy source into its main stream of clean energy.

\section{CHINA'S ENERGY AND ENVIRONMENT POLICIES}

Over 30 years from 1979 to 2009, the average annual growth rate of primary energy consumption in China has been 5.6 percent, while the average annual growth rate of Gross Domestic Product (GDP) was 9.9 percen (EIA, 2013; Kahrl and Holst, 2009; Zhang and Zhao, 2006). The goal of quadrupling of GDP was achieved basically with the support of the doubling of energy consumption with unprecedented attention towards energy conservation efforts. According to the economy's basic policy, the resource-saving target was set so that during the period of the Eleventh Five-year Plan the unit energy consumption GDP would be reduced by about $20 \%$. In order to accomplish the goal of energy conservation, Government of China formulated a series of policies, including legal and economic measures. In 2005, the government promulgated the Renewable Energy Law, which aimed at supporting the wind power projects. Since then the number of installations have been doubling every year (Chow, 2007). In 2009, China pledged the UN climate change summit in New York to increase non-fossil fuels by 15 percent by 2020 and reduce greenhouse gases by 40 to 45 percent comprises to that level in 2005. (FAS, 2013; PEW, 2013) Progress has been made towards achieving the $20 \%$ energy intensity reduction target, having achieved reductions of 2.74 percent in 2006, 5.04 percent in 2007, 5.20 percent in 2008 and 3.61 percent in 2009 , respectively (revised according to the 2 nd national economic survey), which adds upto a total reduction of more than 15 percent so far.

\section{FACTORS FAVOURING THE RENEWABLE ENERGY ADOPTION IN CHINA}

A comparison between solar and wind energy in terms of geographic resources, technology readiness of external know-how and China's intrinsic manufacturing know-how is reviewed to understand how China sees the two energy sources before adoption and diffusion for its energy needs.

\section{RESOURCE ASSESSMENT}

\section{Wind}

China balances farmland to the wind power. For example, lands with slopes greater than 4 percent are not considered for wind power development and

Journal of Technology Management for Growing Economies, Volume 4, Number 1, April 2013 
estimated potential installed capacity shows a potential of upto 5 megawatts per kilo meter square (Li Junfeng, 2012). The onshore technical capacity potential is $2380 \mathrm{GW}$ and a capacity of 25 percent and the estimated technical potential is 5.2 million GWh/yr at a turbine height of 50 metres was more than 1.5 times China's electricity generation in 2007. With increase in tower height to 80 metres the harvesting power increases to 30 percent more. China has rich offshore wind resource and is suitable for grid connected to wind farms of 2380 GW capacity. Figure 4(a) shows the dispersion of wind energy potential.

\section{Solar}

As per 2007 estimates, China has ample solar energy sources that could provide 1.4 billion $\mathrm{GWh} / \mathrm{yr}$. With a 10 percent conversion efficiency, only 0.23 percent of the land area is required to generate the 3.2 million GWh of electricity (Zhang et al., 2012). At present, one fifth of the rooftop area of China (10 billion square metre) can suffice the energy requirements for providing 2200 GW even with a 10 percent conversion efficiency. On an annual basis, it can amount to 2.9 trillion KWh even with 3.6 hours of sunlight per day.

Above facts provide sufficient evidence that China has the necessary potential for energy sufficiency to gain support from the renewable energy sources. Figure 4(b) shows the dispersion of solar energy potential.

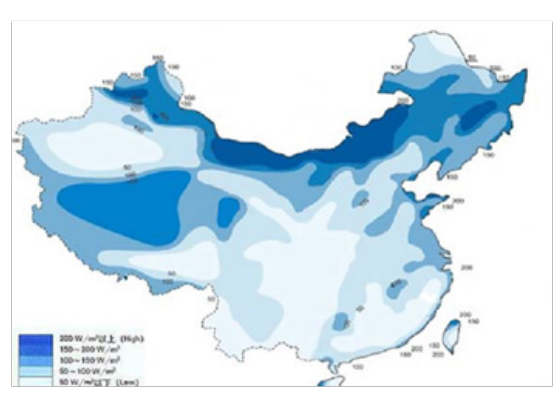

(a)Wind

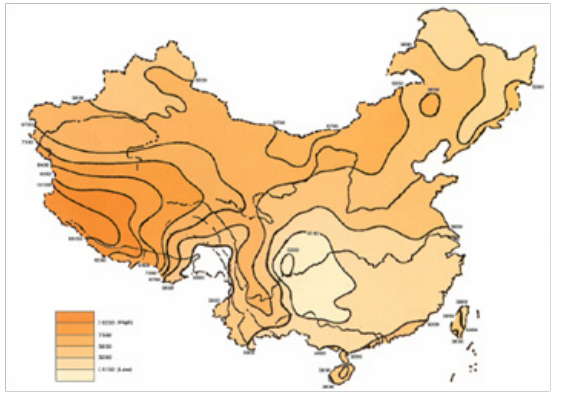

(b) Solar

Figure 4. Wind and Solar resources of China.

Source: Li Jiufeng (2012), Wang Sicheng (2008), China solar PV report-2007, Greenpeace and DBCCA analysis 2011.

\section{Technology Readiness and Change towards Wind and Solar Energy}

A major barrier to mass deployment of a new product such as wind turbines or solar PV equipment is their relatively high cost, lack of know-how, and lack 
Srikanth, N.

Watanabe, $\mathrm{C}$.

of suppliers, lack of intellectual property. The levelized cost of energy (LCOE) generally reflects all the costs including capital cost, maintenance cost and cost due to changes in auxiliary systems such as grid system (e.g., balancing services or backup generation). Ultimately, the LCOE of the new technology (renewable energy) such be cost-effective than the incumbent technology (fossil based energy).

United States has demonstrated to derive energy of more than 70 trillion WH in 2009 which met 1.2 percent of their energy needs. On similar lines, China aimed at achieving 15 percent of its energy needs from renewable energy by 2015 .

China adopted wind turbines and solar energy during a stage when they were externally available as a dominant technology in the western world. For example, China focused on solar crystalline silicon based technology which was a first generation technology in solar PV industry. It was installed on the three bladed horizontal axis product architecture in wind turbines industry which was a matured technology from the developed nations. Hence the product innovation was very matured and helped certainly in investment and technology spillovers. Thus, China had much relevant external know-how for direct knowledge transfer through joint ventures and collaborations and to promote learning from free-open sources such as patents, technical standard and academic publications when it decided to adopt and domesticate these technologies.

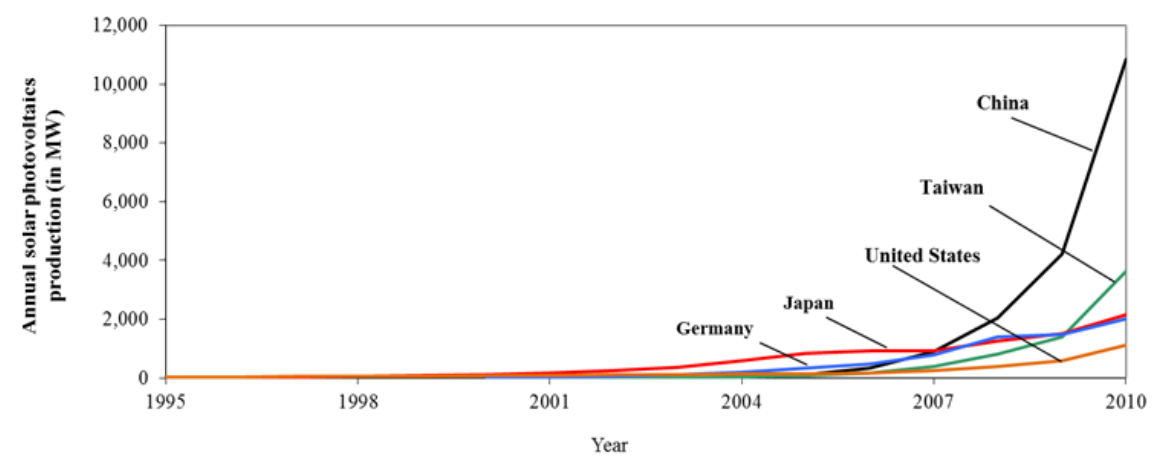

Figure 5: Annual photovoltaic production in major countries (1995 - 2010). Source: Earth Policy Institute (2012). 
Government's

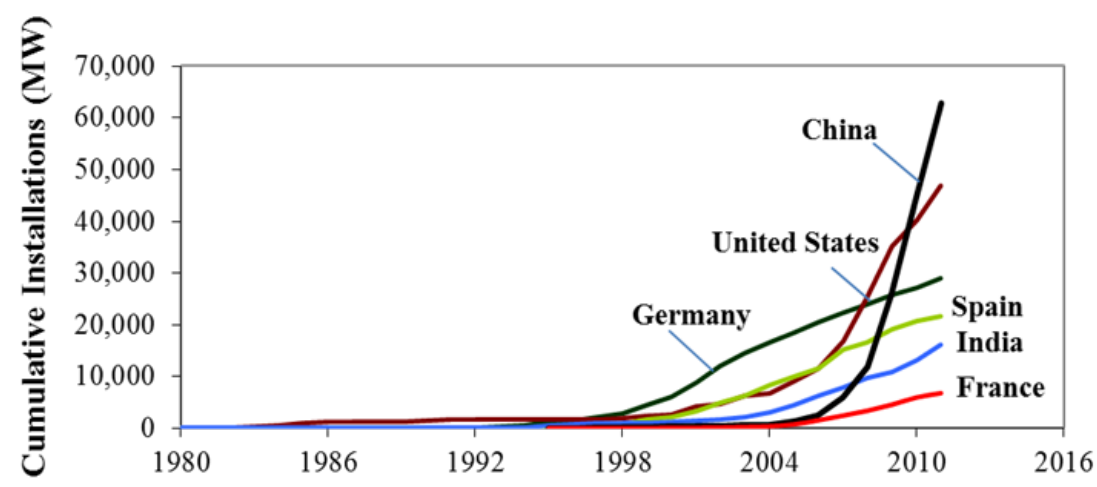

Catalytic Role

Figure 6: Cumulative installation of wind turbine in different countries (1980-2011).

Source: Earth Policy Institute - www.earth-policy.org (2012).

\section{China's Conspicuous Wind and Solar Energy Production}

Supported by the foregoing comprehensive endeavours, China has demonstrated its conspicuous strength in the solar PV manufacturing and wind turbine manufacturing technology and has developed a robust supply chain that meets international production quality as shown in Figures 5 and 6 compared to other parts of the world. However, China has ample resources of wind and solar energy potential and the ample energy demand due to the industrial growth in the two industries can flourish within the country and support the economic growth in a de-carbonized fashion.

From demand side, solar PV diffusion (in terms of deployment and energy generation) lags behind wind power in terms of installed capacity by about five to six years in China. If we overlook the still-unresolved issue of high production costs, $\mathrm{PV}$ sector has grown to a large scale. The preconditions now exist in the solar energy industry for a rapid development similar to the one enjoyed by wind power five years ago. In 2010, China produced $10 \mathrm{GW}$ of PV modules, while total installed capacity in the mainland did not even reach $1 \mathrm{GW}$. It is now imperative for China to actively develop its domestic PV market, and for this it can learn valuable lessons from the development of wind power. These lessons include introducing incentives, establishing initial market conditions, and most importantly, drawing up feasible development goals, ensuring the pricing mechanism benefits to all parties and setting up an overall mechanism that would help connect PV power generators to the grid. 
Srikanth, N.

Watanabe, C.
From the technology supply side, the solar PV has not leveraged the technology licensing and joint venture opportunities with the global counterparts. One reason being the crystalline silicon was matured and had reached a commodity state. Secondly, without sufficient government support the private firms cannot leverage the external know-how from the explicit and tacit knowledge of the global firms, which are wisely combined with the semiconductor know how to develop useful products. These products were disruptive in nature with inferior technologies. However, some process know-how developed for semiconductor industry was useful such as dicing the wafer-fine thickness helped to increase the production volume from the same input stock. These dicing machines and other process machines were common to semiconductor industry and hence the same suppliers of the other industry could neatly align to the needs of the new industry. Example, ASM ${ }^{\mathrm{TM}}$ Technology (Shenzhen) was an established firm making integrated circuit machines, started entering into solar cell packaging machines. Similarly, Applied Materials ${ }^{\mathrm{TM}}$ started entering into solar wafer producing machines. Thus, the support from the government policies for the initial knowledge seeking stage was lacking. Moreover, the internal market during the inception of the solar market was poor in China. Only in the past few years China has been motivating the domestic installations. The industry has purely grown in the support of the export markets. At the same time, China must continue to promote the PV production industry and work towards lowering production costs.

Production costs for wind and solar power are falling: Solar power is already close to grid parity. In some areas, wind power is already economically competitive with coal. Renewable energy, such as wind and solar, has been taking on greater responsibility due to Japan's nuclear accident and unrest in oil production areas. The persistence of electricity grid bottlenecks remains the biggest uncertainty facing wind and solar energy.

According to UNEP (2011) estimates, the technical wind potential in China is $2780 \mathrm{GW}$ and solar PV potential is $2200 \mathrm{GW}$. From the above discussion, it is clear that while wind power adoption has achieved rapid growth, the solar PV adoption has been significantly poor. In contrast to wind, solar PV power adoption was slow due to high development cost despite having rich solar energy resources.

\section{China's Favoured Wind Energy Adoption Compared to Solar PV}

In China, the renewable energies have been rapidly adopted in the last decade (Sinton and Frindley, 2000). However, the fossil based fuels like coal still dominates. There is an increasing level of awareness of the advantages of renewable energy in China such as wide distribution of resources, greater

Journal of Technology Management for Growing Economies, Volume 4, Number 1, April 2013 
utilization potential, less environmental pollution and alternative energy sources.China introduced the "Renewable Energy Law" in 2005 being effective from January 2006, which encouraged development of wind, solar and hydro, biomass, geothermal and ocean energy (Lin (2007)). Table 1 demonstrates their contribution in the recent years taking four major sources of renewable energies in China that gained different levels of developments. Hydro has been a renewable source of power in China and biofuels have non-energy related issues such as land use changes that could lead to higher food prices (Tilman et al., 2009). Next to hydro power, which was considered to be a matured technology, the domestic market installation within China showed a preferable adoption towards wind as compared to solar PV (see Figure 7) which was equally being preferred by countries such as Germany. During the same time period China was capable to supply to the foreign market with the necessary technical and quality requirements. Table 2 critically compares the production and domestic market of wind and solar-PV capability in China. It shows the mismatch between production and domestic market and to creates a curiosity to understand the reasons related to solar and wind installations including policy differences. (Appendix B1 for additional details of the China's renewable energy policies specific to solar and wind industry).

Table 1: Electricity generation from renewable energy sources (2003-

2008)

\begin{tabular}{|l|c|c|c|c|c|c|}
\hline Type of renewable power & $\mathbf{2 0 0 3}$ & $\mathbf{2 0 0 4}$ & $\mathbf{2 0 0 5}$ & $\mathbf{2 0 0 6}$ & $\mathbf{2 0 0 7}$ & $\mathbf{2 0 0 8}$ \\
\hline Small hydro & 95.62 & 92.32 & 91.93 & 90.11 & 85.40 & 78.00 \\
\hline Wind power & 1.76 & 2.07 & 3.06 & 5.59 & 10.51 & 17.32 \\
\hline Biomass & 2.47 & 5.43 & 4.84 & 4.13 & 3.91 & 4.47 \\
\hline Solar PV & 0.15 & 0.18 & 0.17 & 0.17 & 0.18 & 0.21 \\
\hline
\end{tabular}

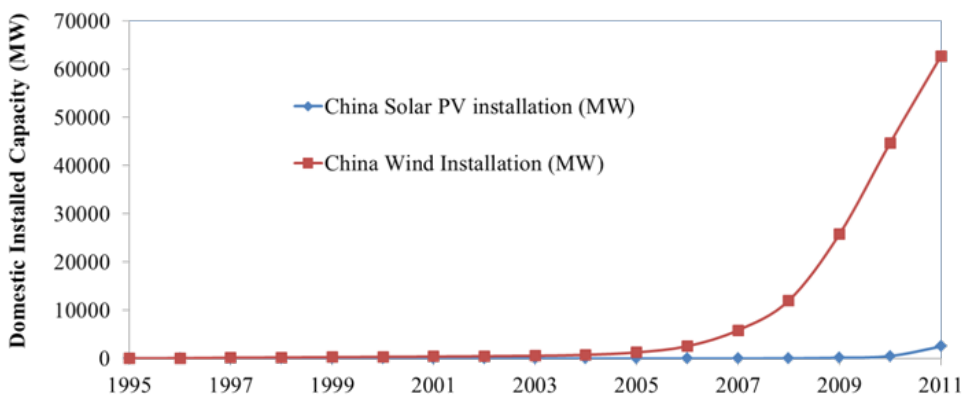

Figure 7: Domestic installed capacity of Solar and Wind installations in China (1995-2011).
Government's Catalytic Role 
Srikanth, N.

Watanabe, C.
Table 2 China's wind and solar PV status: domestic market and production capacity (2011)

\begin{tabular}{|c|c|c|}
\hline $\begin{array}{l}\text { Renew- } \\
\text { able } \\
\text { source }\end{array}$ & \multicolumn{2}{|c|}{ China's progress } \\
\hline \multirow[t]{6}{*}{ Wind } & \multicolumn{2}{|c|}{ Installed Capacity } \\
\hline & & $\begin{array}{l}\text { China is the world's largest market, with } 13.8 \mathrm{GW} \text { added in } \\
2009 \text {, more than one third of the global market. }\end{array}$ \\
\hline & & $\begin{array}{l}\text { Wind capacity was doubled in } 2009 \text { in pursuit of an } \\
\text { ambitious target of installing } 30 \mathrm{GW} \text { of wind by } 2020 \text {. }\end{array}$ \\
\hline & \multicolumn{2}{|c|}{ Domestic industry capacity } \\
\hline & (i) & $\begin{array}{l}\text { Large scale wind market is taking shape rapidly and the } \\
\text { domestic industry is booming. }\end{array}$ \\
\hline & (ii) & $\begin{array}{l}\text { China remains the largest market for small wind tubrines } \\
(2009) \text {. }\end{array}$ \\
\hline \multirow[t]{7}{*}{ Solar } & \multicolumn{2}{|c|}{ Installed Capacity } \\
\hline & & $\begin{array}{l}\text { Total capacity in } 305 \mathrm{MW} \text { in } 2009 \text { (one-third provided by } \\
\text { independent producers off-national grid). }\end{array}$ \\
\hline & (ii) & $\begin{array}{l}\text { Major imbalance between PV production and domestic } \\
\text { market. However rapid expansion planned setting up } \\
\text { ambitious midterm targets for domestic market, } 1800 \mathrm{MW} \\
\text { installed capacity by } 2020 \text {. }\end{array}$ \\
\hline & \multicolumn{2}{|c|}{ Domestic industry capacity } \\
\hline & (i) & $\begin{array}{l}\text { PV industry has been growing rapidly. China is the leading } \\
\text { manufacturer of solar PV panels, with more than } 40 \% \\
\text { share of global PV cell production in } 2009 \text { and about } 50 \% \\
\text { in } 2010 \text {. }\end{array}$ \\
\hline & (ii) & $95 \%$ of production is exported. \\
\hline & (iii) & Most raw materials and equipment are imported. \\
\hline
\end{tabular}

Source: UNEP, Enhancing information for renewable energy technology deployment in Brazil, China and South Africa, 2011.

On the basis of the foregoing observations, aiming at understanding the causes for the difference in adoption rate, the resource availability, technology maturity and commercialization potential are compared. This provides strong evidence that the policy framework affects the renewable energy developments significantly. Therefore, a contrasting study of solar and wind related policy is focused for detailed discussion in this paper.

Journal of Technology Management for Growing Economies, Volume 4, Number 1, April 2013 
ANALYTICAL FRAME WORK

\section{Hypothesis}

Based on the above discussions, following hypothesis can be postulated:

While conspicuous increase in production of China's solar PV and wind can be attributed to effective learning and assimilation of spillover technologies in existing industries, contrasting adoption between wind and PV can be attributed to learning from related domestic industry and foreign wind industries with government's priority inducing policies.

\section{Existing works}

The diffusion of renewable energy technologies have been discussed (Jacobsson and Johnson, (2000) and the role of policy and key actors was discussed. Traditionally Chinese energy policy emphasized on energy efficiency and energy conservation in the last two decades, from 1980 to 2000, during which GDP quadrupled but energy consumption increased twice in order to continue this growth trend from 2000 to 2020, China found its steep energy demand and promoted energy efficiency and set to reduce $20 \%$ reduction target intensity into its 11th five year plan (between 2005 to 2010)(Kahrl; NDRC, 2010 and Holst, 2009). Presently, Chinese energy policy has been formulated based on energy security which is based on its intrinsic energy sources (Buijs, 2011).

A second objective is to limit coal-fired power generation and establishing a strong domestic industry in wind, solar and nuclear energy (Buijs, 2012) in addition to hydropower which is the mainstay of renewable energy. The non hydro renewables are stimulated by policies including feed in tariffs and a renewable energy portfolio standard (RPS) for grid and power companies (Martinot and Li, 2007). For wind energy, the total installed capacity has been doubling in the last four years in a row and the government has revised target of 120 from initial target of $30 \mathrm{GW}$ by 2020 . However, for solar energy the advancement has been poor of less than $1 \mathrm{GW}$ by 2009 with a target of $1.8 \mathrm{GW}$ for 2020 although it is possible to set above $10 \mathrm{GW}$.

China government's policy reforms mainly focused on the allocation of capital investment to energy efficiency through instruments such as low interest loan programs, interest subsidies, tax credits, tax reductions, tax exemptions and setup of energy conservation service centres (Lin, 2005 and Wang, 1995).

Earlier studies have shown the importance of domestic industries in supporting the growth of domestic industry (Est, 1999; Johnson and Jacobsson, 2000). It is highlighted that a country develops an industry to support its own economic and social agenda in its own home market (Connor, 2004). In addition to the existence of the home market and relevant know-how of

Journal of Technology Management for Growing Economies, Volume 4, Number 1, April 2013
Government's

Catalytic Role 
Srikanth, N.

Watanabe, C.

the domestic firms, the key focus lie in the policies which will be dealt in the further sections of this study. However, the aim of this study is to show how policy tools promote the uptake of wind and solar renewables into the energy sources and in the creation of domestic firms and accelerates the uptake of the domestic components into the capital infrastructure of these energy sources. This helps in understanding the importance of the pre-existing relevant knowhow and importance of policies to co-evolve the supply chain in order to grow a new industry in a given region.

Technology has both tacit and explicit knowledge components (Nonaka and Toyama, 2003). To bring appropriate technology to a region, it requires absorption capacity of the local firms, and skills and mobility of local employee (OECD, 2009). The mandate is to give domestic firms access to new product and process technologies of the MNEs, and to facilitate the use of local content and skills in the development of technology of the MNEs, (Feinberg and Majumdar, 2001). Rai et al (2010) showed co-creation as an alternative to technology transfer and demonstrated how co-creation of ICT innovation can enable the emergence of future markets. Agglomeration theory of clusters, typical of knowledge clusters, often attracts direct investments from outside (Lorenzen, 2002). MNEs enter particular cluster to benefit from agglomeration economies that they facilitate (Frost, 2001; Krugman, 1991; Porter, 1998; Saxanian, 1994). They want access to whole group of suppliers and customers, knowledge institutions which are not owned by other firms (Lorenzen and Mahnke, 2002).

In order to support our co-creation of indigenization of future technology supply to support future market conjecture, this paper is organized in discussing the case studies of solar PV and wind energy technology adoption into China during the same time period. In the co-creation mode, it could be argued that technology transfers acts as an initial alignment opportunity where the transferred technology aligns growth and markets of developing countries to the knowledge base of the transferring entity to suffice the market impact (Rai et al, 2010). Further, the indigenization through co-creation of supply chain by the recipient country helps its indigenous technology supply for the future growth and sustenance of its sovereignty and industry growth. Thus, the study grounds and illustrates the co-creation concept by case study analysis and finally drawing the framework. It further discusses the importance of policies favouring co-creation with some pointers.

\section{Focus of the Analysis}

Since the prime objective of this paper is to analyse the catalytic role of government R\&D inducing hybrid management of technology, focus of the analysis can be identified as the interactions of the following institutional

Journal of Technology Management for Growing Economies, Volume 4, Number 1, April 2013 
factors as a system which is demonstrated in Figure 8:

(i) Management of government policy encompassing resource allocation of the nation,

(ii) Government's market inducing policy tools,

(iii) Government inducement of manufacturing industry's strength,

(iv) Enhancement factors of industry's learning ability and mutual interaction between indigenous strength and learning effects.

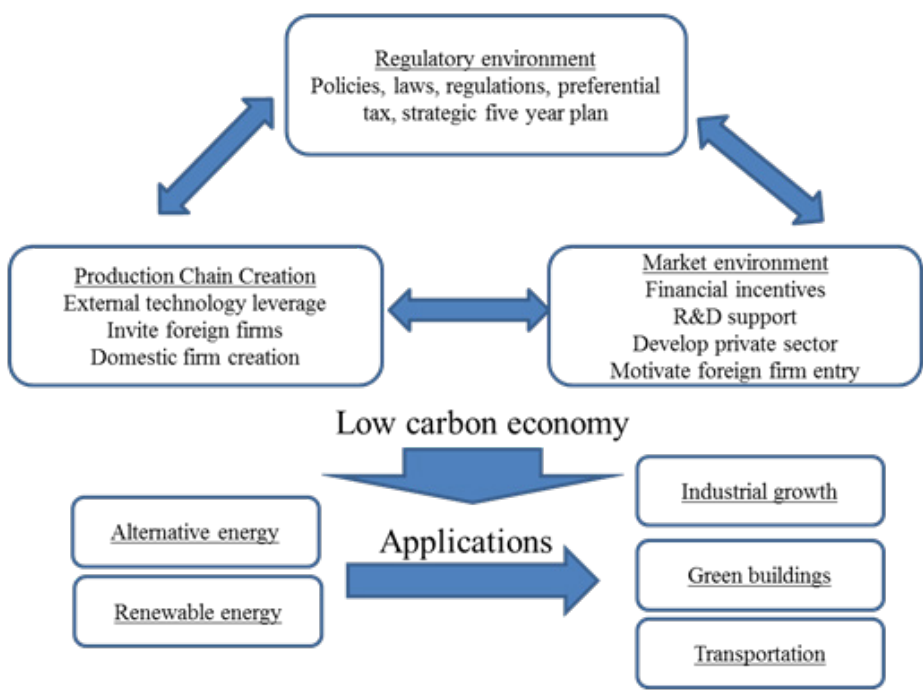

Figure 8: Systems interaction framework to relate the policy tools to cocreate the production chain and domestic market to support a low carbon economy.

\section{Analytical Model Formulation}

Aiming at demonstrating the causal relation between foregoing institutional factors, the following investigations are attempted:

(i) Effects of government's catalytic stimulation,

(ii) Effects of technology stock on functionality development,

(iii) Spillover effect from foreign invested firms to private firms, and

(iv) Effect of technological progress of clusters growth.

(i) Effects of government's catalytic stimulation

The gross production value of the wind and solar industries in China can be de- 
Srikanth, N.

Watanabe, C. picted as a function of the government investment with a time lag that captures the incubation period to materialize implementation as follows:

$$
\begin{aligned}
& Y_{W}=F\left(R_{g W(t-i)}\right) \\
& Y_{S}=F\left(R_{g S(t-j)}\right)
\end{aligned}
$$

where

$Y_{w}$ : yield of China's wind turbine installations in mega watts,

$Y_{s}$ : yield of China's solar PV installation, in mega watts,

$R_{g W(t-i)}:$ indicates government funding to wind with a time lag (t-i),

$\mathrm{R}_{\mathrm{gS}(\mathrm{t}-\mathrm{j})}$ : indicates government funding to solar PV with a time lag $(\mathrm{t}-\mathrm{j})$,

$i$ and $j$ : denotes number of years for wind and solar, respectively, that varies from 0 to 5 .

Taking logarithm, and varying ' $i$ ' and ' $\mathrm{j}$ ' from 0 to 5 the best fit can be identified by taking statistically most significant:

$$
\begin{aligned}
& \ln \left(Y_{W}\right) i=a+b \ln \left(R_{g W(t-i)}\right) \\
& \ln \left(Y_{S}\right) j=a+b \ln \left(R_{g S(t-j)}\right)
\end{aligned}
$$

where $a$ and $b$ : coefficients

(ii) Effects of technology stock on functionality development

The technology stock $(T)$ at time $t$, can be depicted by the following equation:

$$
T_{t}=R_{t-m}+(1-\rho) T_{t-1}
$$

where $T_{t}$ : technology stock at time $t$,

$R_{t-m}: \mathrm{R} \& \mathrm{D}$ investment (fixed prices) at time $t-m$,

$m$ : time-lag between R\&D and commercialization; and

$\rho$ :rate of obsolescence of technology.

Under the competitive circumstances where nation aims at maximizing the productivity of its technology stock, marginal productivity of technology corresponds to the relative price of technology $P_{T}$ as follows:

$$
\partial V / \partial T=P_{T}
$$

Following Zhao and Watanabe (2006), using price of technology $P_{T}$, and na- 
tions technology stock $T$, market learning in fusing global best practice can be depicted by the following function with dynamic learning coefficient as a function of time ' $t$ ':

$$
\begin{aligned}
& P_{T}=A T^{-\lambda(t)} \\
& \lambda(t)=\sum_{i=0}^{n} a_{i} t^{i}
\end{aligned}
$$

Having established an increase in the cumulative production of renewable energy sources that includes solar PV and wind technology, the learning coefficient can be determined. The learning coefficient depicted by $\mathrm{P}_{\mathrm{T}}=\mathrm{A} \sum \mathrm{Y}^{-}$ ${ }^{\lambda}(t)$, where $\mathrm{P}_{T}$ is the fixed price of the product, $\mathrm{Y}$ is the cumulative production, $\mathrm{A}$ is coefficient and ${ }^{\lambda}(\mathrm{t})$ is dynamic learning coefficient as a function of time ' $\mathrm{t}$ '.

Emergence of the new renewable energy functionality development in China was triggered by the government's catalytic inducement initiated by its industrial cluster policy. It stimulates to assimilate the spillover technology from related foreign invested firms into renewable industries to develop indigenous products such as wind and solar energy equipment production and installation. It also induces fusing technologies that are licensed from international firms and by accessing global open access knowledge such as patent database and design standard. Thus, the strategy has helped maximize the marginal productivity of technology $(\mathrm{MPT})\left(=\partial \mathrm{RE}_{\mathrm{r}} \partial \mathrm{T}\right)$, where $\mathrm{RE}_{\mathrm{T}}$ is the renewable energy and its technology stock $\mathrm{T}$ is created by accumulating the $R \& D$ investment $(R)$. An increase in the technology stock enhances renewable energy's functionality development, as demonstrated by the epidemicfunction depicted in equation (9).

$$
\left(\partial R E_{T} / \partial T\right)=a R E_{T}\left(1-\frac{R E_{T}}{N}\right)
$$

where $a$ : velocity of diffusion, and $N$ : carrying capacity, this is raised by the new generation invention and diffusion (Meyer and Ausbel, 1999).

From equation (9), diffusion trend in the renewable energy uptake can be depicted by the following logistic growth function:

$$
R E_{T}=\frac{N}{1-\exp (-a T-b}
$$

where $b$ : the initial state of diffusion.

(iii) Spillover effect from foreign invested firms to private firms

The inter-dependency of private firms on the foreign firms' technology stock 
Srikanth, N.

Watanabe, C.

can be studied by composing the production function of a set of private firms specific to machinery and accounting the spillover of the technology stock from foreign firms at national level. One method is to compute the independent technology productivity function of the foreign firm as follows:

$$
Y_{F}=A_{F} L_{F, j}^{\alpha_{F}} K_{F, j}^{\beta_{F}}
$$

where

$Y_{F}$ : foreign firms' production,

$A_{F}:$ scale factor,

$\alpha_{P} \beta_{F}$ : coefficients,

$j$ : specific sector of industries,

$L_{F}$ : foreign firms' labour stock, and

$K_{F}$ : foreign firms' capital stock

Taking logarithmic form and computing the total factor productivity (TFP) for different industries, as follows:

$$
\ln \left(T F P_{F, j}\right)=\ln \left(Y_{F, j}\right)-\alpha_{F} \ln \left(L_{F, j}\right)-\beta_{F} \ln \left(K_{F, j}\right)
$$

where : total factor productivity of $j$ th sector of industries.

Given that the domestic private firms utilize TFP spillover from foreign firms by assimilating it, the productivity function of the domestic private firms can be computed by accounting the foreign firms' technology stock of same type of industrial sector as follows:

$$
Y_{P}=A_{P} L_{P, j}^{\alpha_{P}} K_{P, j}^{\beta_{P}} T F P_{F, j}^{\gamma_{P}}
$$

where,

$Y_{P}$ : domestic private firms' production,

$A_{P}$ : scale factor, and

$\alpha_{\mathrm{p}}, \beta_{\mathrm{P}}, \gamma_{\mathrm{p}}$ : coefficients,

Expressing in logarithmic form as follows:

$$
\ln \left(Y_{P}\right)=\ln \left(A_{F}\right)+\alpha_{P} \ln \left(L_{P, j}\right)+\beta_{P} \ln \left(K_{P, j}\right)+\gamma_{P} \ln \left(T F P_{F, j}\right)
$$

(iv) Effect of technological progress of clusters growth

The gross production value of the heavy industries of different region in China can be depicted as a function of the employees and total capital assets as fol-

Journal of Technology Management for Growing Economies, Volume 4, Number 1, April 2013 
lows:

Government's

$$
Y_{i}=F\left(L_{i} K_{i}\right)
$$

where subscript ' $i$ ': indicates region.

Expressing in Cobb-Douglas type production function and taking logarithm, total factor productivity $(T F P)$ can be predicted as follows:

$$
\ln \left(T F P_{i}\right)=\ln \left(Y_{i}\right)-\alpha \ln \left(L_{i}\right)-\beta \ln \left(K_{i}\right)
$$

where $\alpha, \beta$ : coefficients.

\section{DATA CONSTRUCTION}

The present study utilized data such as gross domestic product (GDP), national R\&D investment, patent and journal paper statistics, industrial statistics from World Bank data. Since China (OECD Science and Technology statistics) does not belong to OECD members countries, it was difficult to get data on multifactor productivity. Therefore, China statistical data (2011) was referred to obtain the time series at the national level and the regional level for the year 2010.

In modeling the technology spillover from foreign firms to domestic firms the machinery sector and 41 sectors responsible for the wind and solar PV industry's supply chain were chosen and their labour, capital stock of domestic and foreign invested firms were analysed.

In modeling the quality, China's regional manufacturing competitiveness was used as a measure for different regions. The FDI data related to investment in assets, employment and industrial output were obtained from China's official FDI website. Information regarding patents, exports and overall country level data were referred from OECD and World Bank data.

\section{RESULTS OF THE ANALYSIS}

In the following sections the empirical findings at national, regional and cluster level are discussed.

\section{Empirical findings}

\subsubsection{Effects of the stimulation}

(i) Inducing effects of government R\&D support

The production dependence on government support for wind industry was found to be:

$$
\begin{aligned}
\ln \left(Y_{i}\right)= & 6.650+0.796 \ln \left(R_{g_{-} W(t-2)}\right) \quad \text { adj. } R^{2}=0.988 \\
& (9.97)^{* * *}(3.22) * * * \\
& * * * \text { Significance at the } 1 \% \text { level. }
\end{aligned}
$$


Srikanth, N.

Watanabe, C.

The production dependence on government support for solar PV industry was found to be:

$$
\begin{aligned}
\ln \left(Y_{i}\right)= & 5.804+0.809 \ln \left(\mathrm{R}_{g_{-} P V(t-2)}\right) \quad \text { adj. } \mathrm{R}^{2}=0.893 \\
(7.58)^{* * *} & (10.49)^{* * *}
\end{aligned}
$$

*** Significance at the $1 \%$ level.

(ii) Effect of technology stock on functionality development

The technology stock was computed and plotted against the patent stock which shows the increase of domestic patents applications and granted publications as shown in Figure 9.

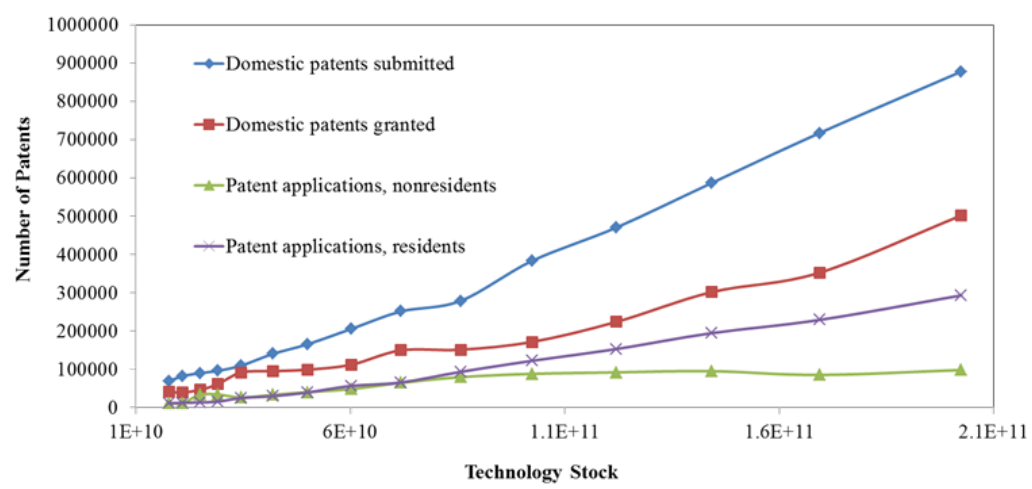

Figure 9: Industry patent stock trend with technology stock in China (19932006)

The learning coefficient of China's overall renewable energy adoption as shown in Figure 10 was empirically found using backward elimination method (BEM) with $1 \%$ significance criteria which is as follows:

$$
\begin{aligned}
\ln \left(P_{n}\right)= & 162.474-\left(4.122-0.310 \mathrm{t}+0.028 \mathrm{t}^{2}-5.076(10)^{-6} \mathrm{t}^{4}\right) \ln \left(\sum \mathrm{RE}\right) \\
& (0.66)^{* * *} \quad(-4.44)^{* * *}(-2.58)^{* * *}(4.23)^{* * *} \quad(-4.26)^{* * *}
\end{aligned}
$$

*** Significance at the $1 \%$ level. $\quad$ adj. $\mathrm{R}^{2}=0.979$ 


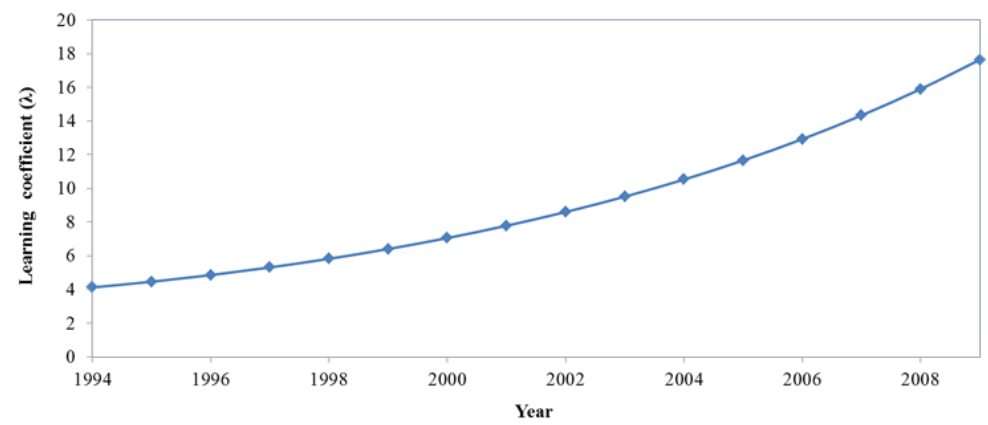

Government's

Catalytic Role

Figure 10: Trend in learning coefficient with respect to renewable energy

(1994-2009)

The uptake of the renewable energy in China which includes the solar and wind energy can be modelled as a logistic model which is as follows:

$R E_{T}=\frac{6 E 12}{1-\exp (-(6.145 E-22) T-6.579 E-11)}$

The above evidences confirm the increase in technology stock with the learning and assimilation efforts.

\section{(iii) Spillover Effect from Foreign Direct Investment}

The increasing productivity of hi-technology products from domestic firms as shown in Figure 11 with world class features are evidences of the assimilation capability derived from the foreign firms' know-how and mobility of labour stock from foreign firms to domestic firms. In the earlier study on solar industry (Srikanth and Watanabe, 2012) patents analysis results showed the assimilation capability of wisely fusing the external know-how with domestic know-how of similar technology class to the new industry need, which demonstrates the searching, absorbing, assimilating and transforming skills of the work force.

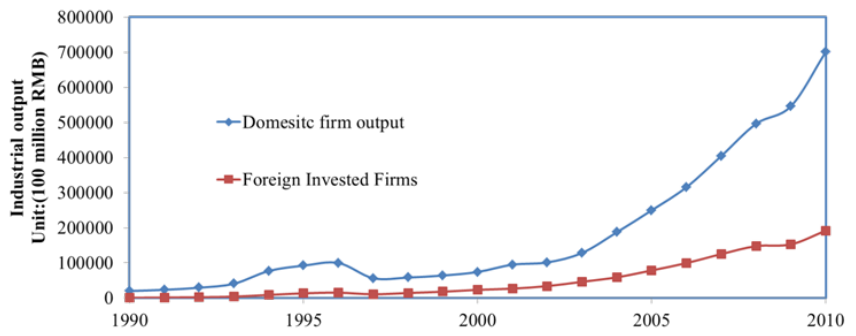

Figure 11: Industrial output trend in domestic firms versus foreign invested firms (1990-2010). 
Srikanth, N.

Watanabe, C.

The present empirical analysis showed the production function of the private firms with respect to 100 heavy industrial products shows interdependency of the foreign firms' technology effects based on equation (13) is found to be:

$$
\begin{array}{r}
\ln \left(Y_{P}\right)=3.837+0.686 \ln \left(L_{P, j}\right)+0.332 \ln \left(K_{P, j}\right)+0.479 \ln \left(T F P_{F, j}\right) \\
(0.479)^{* * * *} \quad(5.91)^{* * *} \quad(2.79)^{* * *} \\
* * * \text { Significance at the 1\% level. } \quad \text { adj. } \mathrm{R}^{2}=0.990
\end{array}
$$

From the above empirical finding, it is clear that the elasticity of productivity with foreign firms TFP which is identified as 0.479 clearly indicates the foreign firm's technology stock contributes to the domestic firm's productivity, through spillover and labour mobility.

(i) Effect of clusters' technological progress

The production function for different region's industrial sector, illustrated in Figure 12, is given by:

$$
\begin{aligned}
& \ln \left(Y_{i}\right)=6.041+0.584 \ln \left(L_{i}\right)+0.586 \ln \left(K_{i}\right) \quad \text { adj. } \mathrm{R}^{2}=0.978 \\
& (28.41)^{* * * *}(4.10)^{* * * *} \quad(5.14)^{* * * *} \\
& * * * \text { Significance at the } 1 \% \text { level. }
\end{aligned}
$$

The TFP was computed based on equation (16) and is demonstrated in Figure 13.

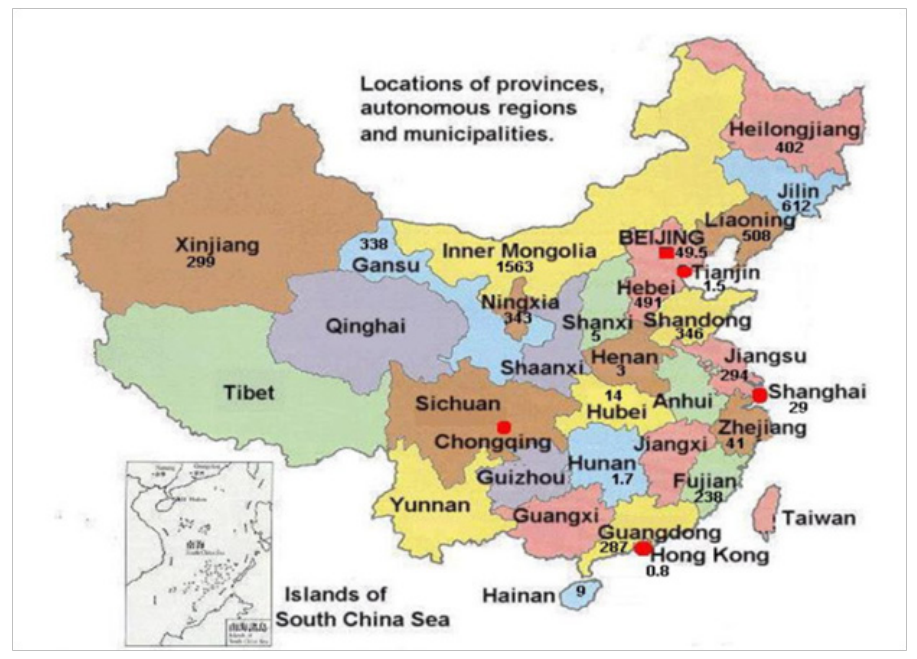

Figure 12: Different regions of China taken for analysis 


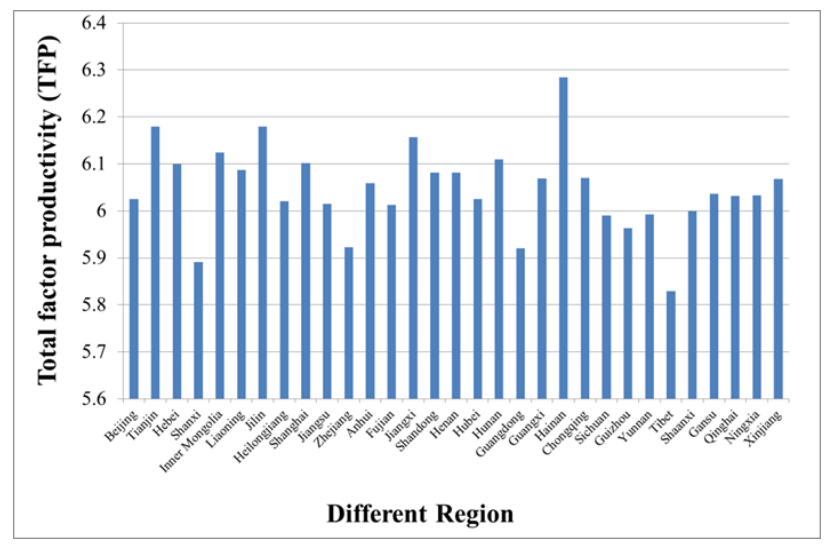

Government's

Catalytic Role

Figure 13: Technological progress of different region of China in heavy industry (2010)

The above regional performance of clusters in heavy industry matches well with the actual observation of wind industry manufacturing in Hebei, Inner Mongolia and Tianjin. For example, the Tianjin industrial cluster is formed due to the development of state owned enterprises as foundation to cooperate with foreign companies, together with lower costs and improve market reaction to become competitive worldwide. In addition, large number of existent trained skilled industrial technical workers to suit heavy industry and has more than 850 wind power manufacturers and suppliers, including domestic and foreign firms. Total investment of 12.645 billion Yuan and a total workforce of 24,760, have formed the most complete system in China's wind power industry. Its annual capacity is $5600 \mathrm{MW}$ of turbines that encompasses generator, blade and gearbox skills.

Such success lured Vestas a foreign firm to establish itself in Tianjin cluster during 2005, to setup a factory with a $\$ 363$ million this making it an important manufacturing base in China. Choice of selection of this cluster was due on the basis of its location and infrastructure (Renewable energy today, 2006). As of now, it has developed a strong value chain with 80 odd local suppliers. Spain-based Gamesa Corporation and India-based Suzlon Energy has follow suit of such investments in Tianjin. In 2009, Vestas started core technology components (control systems, and precision components) and introduced new product that was designed for the China's terrain and was locally produced and for the region $\mathrm{V} 60-800 \mathrm{KW}$ model to meet China's domestic content policy requirement. 
Srikanth, N.

Watanabe, C.

\section{SYSTEMS INTERPRETATION}

\section{Systems efficiency}

Diffusion process of innovative goods can be depicted by the following epidemic function with its carrying capacity $N$.

$$
\begin{aligned}
& \frac{d}{d t} V(t)=a V(t)\left(1-\frac{V(t)}{N}\right) \\
& V(t)=\frac{N}{1+e^{-a t-b}}
\end{aligned}
$$

where $V(t)$ : cumulative number of innovative goods; $N$ : carrying capacity; $a$ : velocity of diffusion; $b$ : initial stage of diffusion; and $t$ : time trend.

Under the presence of a catalytic role of the government with clear expectations such as the Renewable Energy Law of 2005, domestication expectation, technology seeking and market identification support. The various actors in the value chain are ready to support the national expectations. This induces the assimilation capacity of the manufacturing clusters that has the right know-how such as heavy industry technologies in terms of labor stock, patents and intellectual property (IP), to suit the identified industry of the government such as wind or solar industry. This in turn the velocity of production (V) and enhances the functionality development. Such functionality development (FD) emerges in the various segments of the value chain such as design transformation to meet regional need with the support of customer. It meets the national target with support of production and adoption. The increase in the functionality development further increases the marginal productivity of technology which is the partial derivative of the change in production to the technology stock. The technology stock can be further shown that it accrues with the increase in the assimilated knowledge such that it increases with assimilation as show in the following equation:

$$
T(t)=T_{i}(t)+z(t) T_{s}(t)
$$

where $\mathrm{z}(\mathrm{t})$ : the assimilation capacity which depends on the firm's skilled laborers, absorption capacity and prior knowledge stock.

$\mathrm{T}_{\mathrm{s}}(\mathrm{t})$ : spillover technology of the other related industry from lo cal industries, and

$\mathrm{T}_{\mathrm{s}}(\mathrm{t})$ : total technology stock at time $\mathrm{t}$.

Thus, increase in technology stock with assimilation will induce more assimilation capacity and thereby will induce more functionality development

Journal of Technology Management for Growing Economies, Volume 4, Number 1, April 2013 
and more assimilation of spillover technologies. Thus this forms a virtuous cycle between assimilation, functionality development and agglomeration of technology stock in industrial clusters as illustrated in Figure 14.

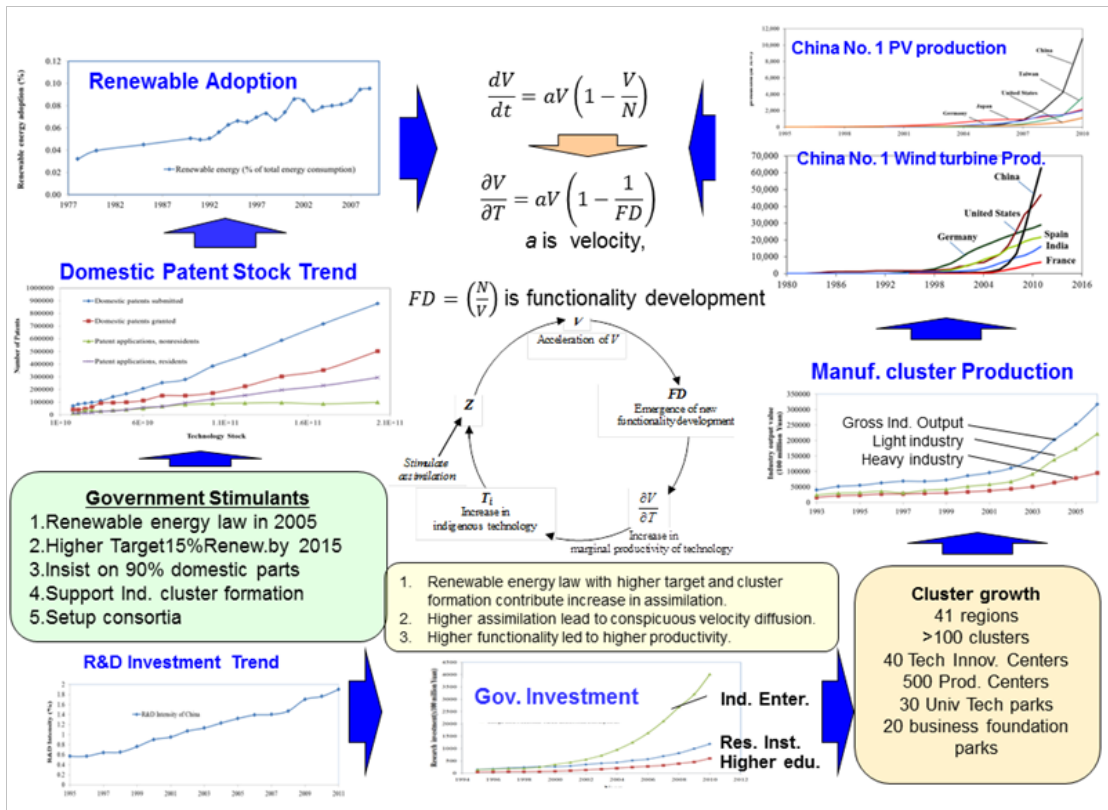

Figure 14: Government catalytic role inducing virtuous cycle between assimilation capacity increase and acceleration of the emergence of functionality development.

The above mechanism could be accomplished with proper national level institutional system which China that is capable to assess the core-capabilities of its resources such as industrial clusters, academia and research institutes to support in a symbiotic way to support the assimilation process. Tables A4, A5 and A6 in Appendix show the statistics of institutional increase in academia, research institution and industrial clusters that were responsible in the learning and assimilation process. On the demand side the national innovation system should be capable to evaluate the internal and external market demand and co-evolve a market with the expectations in terms of technology, product features against the existing choices. Figure 15 shows the various elements of the input and output components of the overall national innovation system. Such a system under the catalytic stimulation of the government, initiates the assimilation, transformation and acclimatization by following acclimatization process as shown in Figure 16 to support the functionality development. 
Srikanth, N.

Watanabe, C.
Innovation generation Cycle

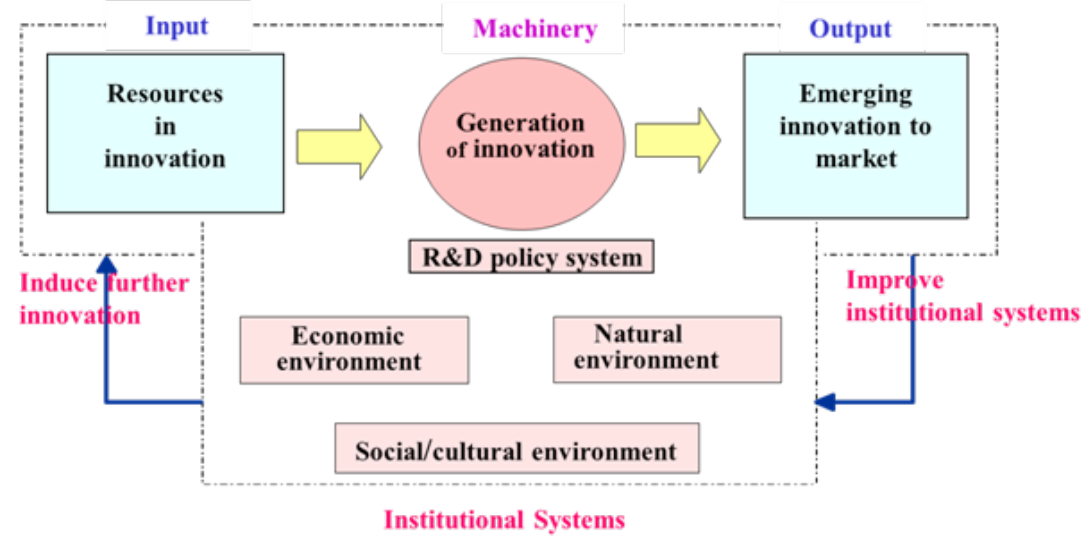

Figure 15: Overall institutional systems of China's national innovation system and indigenous innovation generation scheme.

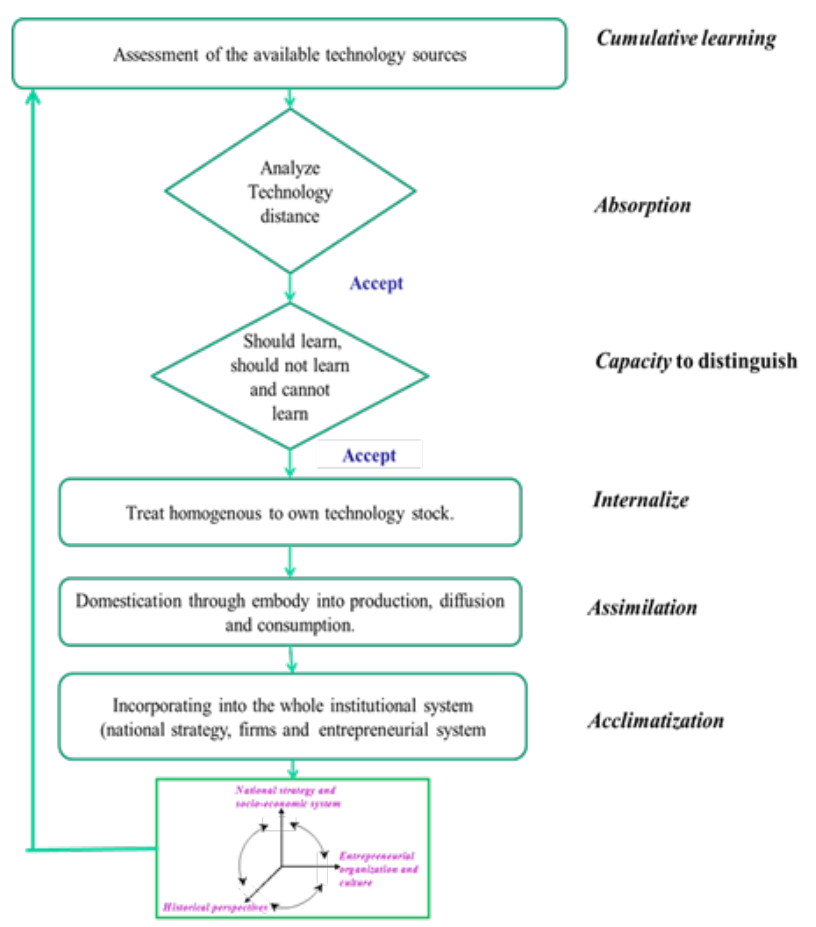

Figure 16: Process to acclimatize the assimilated knowledge to support the functionality development. 


\section{Catalytic role technology acquisition path differences observed between Chinese solar PV and wind manufacturing firms}

Comparing the two industries solar PV and mega wind turbines we find that both industries have demonstrated conspicuous development strength in production. However, detailed analysis shows that solar PV industry resides the first generation technology (crystalline silicon technology), while the foreign firms are working in second and third generation technologies (viz., thin film Catalytic Role

$\mathrm{PV}$ and organic solar industry). Thus, we see that the economic growth model of this industry is purely dependent on the gross output ' $V$ '.

where $V$ : production output,

$X$ : traditional resources as labour $(\mathrm{L})$ and capital $(\mathrm{K})$,

$R$ : R\&D investment,

$F D$ : functionality development,

$a$ : diffusion coefficient, and

MPT: Marginal productivity of technology.

However, in the case of wind turbines, the functionality development measured in terms of capacity of the turbines has been increasing steadily with the indigenous technology and has reached the performance of the foreign firms. Thus, the MPT grows with functionality increase and thereby increases the production output of the firms. This is more preferred as it motivates new innovation than purely investing into the production resources. Thus, the case of stimulating FD is a preferred choice to enhance MPT and thereby the growth.

$$
\begin{gathered}
\frac{\Delta V}{V}=\sum_{X=L, K}\left(\frac{\partial V}{\partial X} \cdot \frac{X}{V}\right) \frac{\Delta X}{X}+\frac{\partial V}{\partial T} \cdot \frac{R}{V} \\
\frac{\partial V}{\partial T}=a V\left(1-\frac{1}{F D}\right)
\end{gathered}
$$

Figure 17: Production focus of China's solar PV industry.

Comparing the two cases' technology acquisition path, solar PV industry shows the least evidence of direct technology transfer. However, the evidence of rise in the solar industry rise in and their leading production capability of 
Srikanth, N.

Watanabe, C. indigenous products of global standard along with the domestic semiconductor industry shows the technology spillover evidence through utilization of global best practises of foreign solar multinational companies (MNCs) and fusing with local domestic semiconductor know-how. The present findings show that supply chain in China has high dependency on foreign imports for raw materials and foreign markets for deploying the solar panels. Thus, the dynamics of the foreign players greatly affect China's supply chain and thereby the functionality development. This trend may extend to future technologies too, since China's production has been purely focusing on the first generation technologies as compared to USA and Europe that have been focusing on second and third generation technologies.

$$
\begin{aligned}
\frac{\Delta V}{V}=\sum_{X=L, K}\left(\frac{\partial V}{\partial X} \cdot \frac{X}{V}\right) \frac{\Delta X}{X}+\frac{\partial V}{\partial T_{\uparrow}} \cdot \frac{R}{V} \\
\left.\frac{\partial V}{\partial T}=a V\left(1-\frac{1}{F D}\right)\right)
\end{aligned}
$$

Figure 18: Functional development focus of China's wind industry.

On the contrary, the technology acquisition path of China for wind industry has been robust that has transformed from a state of technology scarcity condition to total indigenisation. The results can be seen in terms of increasing functionality (such as large geometric size and capacity). This resulted in increasing market share to become world leading domestic producers and adopters. The study showed that the wind industry does import some of the key technologies such as control systems and precision bearings; however, their proportion has been reducing with growing indigenization such that domestic firms with indigenous products support China's wind turbine installation up to $90 \%$ as of 2011 . The success to such world dominance is in setting up the symbiotic institutions of production and adoption which can be attributed to the catalyst role of the government to assimilate and transform into indigenous products in the early stage of the solar PV and wind industry.

\section{SIGNIFICANCE OF CATALYTIC ROLE OF GOVERNMENT POLI- CIES}

\section{Co-evolution of a Domestic Production Chain with Adoption}

In the wind industry, the policies began since the late 1990s but they did not generate impact both on the production side and on the market creation side

Journal of Technology Management for Growing Economies, Volume 4, Number 1, April 2013 
which cater to the energy needs due to lack of incentives. Hence by 2003, only a meagre installation of $0.56 \mathrm{GW}$ was achieved which catered for 0.15 percent of the country's energy needs. In 2003, concessional projects dictated 70 percent of domestically manufactured components, which encouraged domestic firms to evolve and assemble the turbines within China. These policy tools helped the domestic firms. These requirements greatly reinforced the market and production chain to become stable, with foreign direct investments into Chinese facilities reached to a level of US\$ 34.6 billion. The upcoming local wind turbine brand names such as Gold wind and Sinovel exhibited the advanced stage of maturity of the renewable energy segment in China.

\section{Importance of Local Content Requirement for Indigenization}

Although China is on course of rapid adoption of wind turbine, its technology and manufacturing capacity was not capable to match its demand in 1995. Therefore, China had to rely on the foreign turbine manufacturers. Economies of scale in production helps in reducing the cost of electricity and price of wind turbines due to the learning curve concept. The monopoly behaviour of these foreign turbine manufacturers kept the prices of turbines rising as China's order size is growing. China initially subsidized foreign turbine imports. However, it realized the monopoly behaviour of the foreign turbine manufacturers resulted in steady increase in prices. Hence, China's policy focused in prompting the importance of domestication and included the role of local parts of atleast 70 percent and insisted in assembling within the Chinese territory to encourage the technology spillover and domestication of manufacturing technologies. This resulted in co-evolving a production chain to support wind energy adoption in China. This was originally proposed for the concession projects and later extended to normal projects. Thus, with initial bidding mechanism along with the domestic requirement speeded up the localization of the wind turbine manufacturing. By the year 2007, the installed capacity of domestically made turbines exceeded that of foreign ones. By the year 2009, with consistent domination of the domestic players with increasing shares, China abolished the local content requirement practice in November 2009 (Zhang, 2010). By the end of 2011, China had $62.4 \mathrm{GW}$ wind turbines installed but only 45 GW of this was connected to the grid. As of 2012, China has achieved grid connected wind power to $52 \mathrm{GW}$ (Wu, 2011a). The state grid said China's annual connection rate for wind turbine had grown at an average rate of $87 \%$ from 2006 to 2011. In China's five-year economic plan for 2011 to 2015, the government has already set out its intention of prioritising the development of $3 \mathrm{MW}$ to $5 \mathrm{MW}$ onshore and $5 \mathrm{MW}$ to $10 \mathrm{MW}$ offshore wind turbines (Wu, 2011b). During the same period, the National Energy Bureau has said it will

Journal of Technology Management for Growing Economies, Volume 4, Number 1, April 2013
Government's

Catalytic Role 
Srikanth, N.

Watanabe, C. complete five $10 \mathrm{GW}$-wind projects. It will also begin to construct the $2 \mathrm{GW}$ wind farms in Hami of Xinjiang, 2GW wind farms in Kailu of Inner Mongolia, and 1.5 GW wind farms in Tongyu of Liaoning Province. China will start to construct the $1 \mathrm{GW}$ offshore wind farms in Jiangsu, and push ahead with the development of offshore wind farms in Hebei, Shandong, Zhejiang and Fujian provinces. It will also complete the second phase of Shanghai East Sea Bridge Offshore Wind Farm. According to the, industry officials, China will gradually move away from relying solely on onshore wind farms.

In 2011, China dominated the Ernst and Young index of the most attractive country for wind power development. China lead on 78 points with a 12 point lead over the second placed country Germany. USA and UK are in the third \& fourth spots respectively (James, 2011.

\section{Importance of Domestic Market to Indigenization}

Comparing solar PV industry with the wind industry of China, the government had taken a slow start in creating domestic market for its PV products compared to the production chain formation. Moreover, such program are observed to have focused more on a demand based policy wherein the drive to create large scale PV (LSPV) systems were aimed at achieving from independent village supportive PV deployment. This is good but yet it has not helped to reduce the cost of energy to the necessary extent compared to the fossil fuels.

A closer look at China's production chain of PV industry will show that the industry is poor in technology at the raw material such as pure-silicon sourcing. Its internal demand has not met the overall demand. In addition, the industry is still in its first generation PV technology and invested is not much in the upcoming thin film PV technology and organic solar technology, which is led by USA and Germany. This lack of foot print on those disruptive technologies will affect the further competitiveness of China's solar PV industry in further years.

\section{Additional Barriers from China's Lack of Complimentary Technologies' Maturity to Support Renewables}

Firstly, successful renewable energy transfer requires robust grid infrastructure. In countries such as China, the wind and solar energy rich sites are at significant distances apart from the power demand locations where manufacturing industries and domestic urban environments are located. This demands for a unified national electricity grid. China has six regional grid clusters, which spans both at partially within the 26 provinces and thus trading (takes places both in-between regional grid cluster and in-between grid cluster level). For example, in 2009, the inter-regional electricity trade was only 532 TWh (Cheung, 2011). Hence new technologies such as high voltage lines to support

Journal of Technology Management for Growing Economies, Volume 4, Number 1, April 2013 
AC and DC grids are needed to be laid similar to road infrastructure for transport. Twelfth five year plan has outlined efforts for large scale smart grid system that would demand 40 billion US dollars.

Secondly, renewables such as wind and solar are variable in their power supply. Thus, connecting these variable distributed energy sources will confirm a steady energy supply to the nation's needs (Chandler, 2009), failing which the penetration of the wind or solar energy into the regular energy stream becomes minimal. Even, successful countries such as Denmark have shown a maximum wind energy penetration of only 20 percent. This is one reason for non-variable power generation sources from fossil fuels will continue to dominate the country's energy mix in the near future due to high certainty. Hence long distance cross regional power transmission infrastructure needs to be a part of the country's strategy.

Thirdly, good forecasting tools to predict wind and solar energy should be developed by academic circle for the country to minimize uncertainty from the natural causes.

Thus, regional electricity transmission, flexible generation, demand side management and energy storage technologies become important.

\section{CONCLUSION}

\section{General summary}

For a de-carbonized state of a nation, sustained efforts of private and government actors are important to bring changes. Country and industry specific development challenges are being studied to form working recipes that payoff in quick and large way. China's demonstration of a conspicuous strength in wind power adoption diffusion in the year 2007 interests the world community, especially the emerging countries.

Present successes show that China did not wait to achieve perfect business conditions to stimulate growth; rather it co-evolved the institutional changes by having the government as the catalyst in these reforms. It identified its weakness and leveraged the global strength in technologies along with the local accumulated technology stock of both people and explicit knowledge with present prevailing situations that are the second best in condition. One such evidence is that its pro-growth government policies have been good and helped to draw private investment and innovation to fulfil the shortage in the investment gaps. Still now World Bank ranks China as successful in certain sectors to nurture international firms.

\section{Noteworthy Findings}

China's conspicuous accomplishment in PV and wind production has been possible due to the government's catalytic role. This helped to initiate

Journal of Technology Management for Growing Economies, Volume 4, Number 1, April 2013
Government's

Catalytic Role 
Srikanth, N.

Watanabe, C. assimilation of technologies in order to increase functionality development which exhibits increased marginal productivity of technology and resulted in increased technology stock thereby, resulting in increased assimilation and operated as a viscous cycle between assimilation and functionality development). Such a phenomenon was possible due to the government's establishment of institutions such as industrial clusters, academia and research institutes and creates an apt climate to assimilate the spillover knowledge towards functionality development.

The momentum gained by the manufacturing industry since 2000 in China contributed to the sustaining of competitive factors to new industries like wind and solar industry. Contrast between wind and PV on adaption shows that China co-evolved wind market in tune with country's energy goals, with proper demand side policies that supported the production stability. While solar industry targeted export market because the domestic market policies were lacking and failed to support the country's energy goals even with enough solar resources.

\section{General Suggestion Renewable Energy Policy Recommendations}

The Chinese government issued the Twelfth Five Year Plan at the end of 2010, which aimed at consolidating and improving established sectors where inefficiencies still reside and promote the fast development of seven new strategic sectors including energy and technology areas. The strategic sectors, if sustained successfully, will serve as platforms to supply the domestic market and global markets. These are the sectors where China plans to use its resources and current strong competitive positioning to become indigenous and dominant manufacturer.

Demand and supply for science and technology development are considered important driving forces and government's policy instruments such as direct funding and tax incentives is well documented. However, the implementation should be clearly lined up through an integrated policy system whereby, the science and technology institutions should be interlinked with the industrial $R \& D$ institutions as in the case of Singapore and Japan.

1. The economic potential of a renewable energy source depends on two major factors the yearly production capability and the cost-effectiveness for the electricity produced. The success of these new technologies to a new region depends on the capability of the cost-decreasing path of learning and economies of scale and thereby the market size of the region. Today both wind power and solar power costs are still a few cents/kWh higher than the traditional fossil fuel based power costs in China. Hence effective policy tools are required to promote the adoption and diffusion of wind and solar power in new region. The Twelfth Five Year Plan will usher in the next development stage for wind and

Journal of Technology Management for Growing Economies, Volume 4, Number 1, April 2013 
solar energy, both of which will be vital to optimizing China's energy structure and reducing greenhouse gas emissions. This cannot be achieved without the support of a more detailed and active policy systems, and solution to the issues of high production cost and grid connection difficulties.

2. Recommendations for China's wind energy policy

China's wind energy policy has more favoured in the past to the onshore wind turbine deployment. Taking countries such as UK, it is clear that in order to support "increasing returns to geometric scaling" such as development of large rotor or tall towers, China needs to venture into offshore wind industry in which the space requirement is minimized. In this market too, the west leads over the east and hence China should continue the knowledge spillover mechanisms from developed global firms.

\section{Solar PV Policy recommendations for China}

Still China's PV industry production chain lacks key raw materials such as silicon material and key technology needs (such as circuit topology and Maximum Power Parity (MPP) control method and grid-connect) for new generation solar PV. Hence the government should step in to provoke technology transfer and motivate domestic players to assimilate the useful knowledge with domestic know-how to internalize and improve its existing practices.

In terms of technology, still China's production chain lies in the first generation solar PV industry and has to catch with USA and Japan in terms of thin-film and organic solar PV technologies. The reason being, these disruptive technologies are promising to provide lower cost of energy and will weight out the crystalline solar PV industry.

\section{Recommendations for China's domestic solar industry}

China has exhibited its conspicuous strength in solar cell and module manufacturing but suffers from the silicon material required for its ingot preparation. Moreover, at the final end of the supply chain it heavily depends on the export market. Today with USA and Europe blaming China for dumping in their soil below manufacturing price and claiming that it violates the WTO rules, it becomes clear that China should ramp up its internal domestic market.

\section{Recommendations for China's domestic wind industry}

The wind industry must look beyond the local environment and must go for a global market. Presently, China's wind industry lacks complimentary technologies such as high power fault tolerant grids. This is a barrier to renewable adoption. Similar to the countries like UK, China should plan to extend its domestic market towards offshore conditions. Demand and supply

Journal of Technology Management for Growing Economies, Volume 4, Number 1, April 2013
Government's

Catalytic Role 
Srikanth, N.

Watanabe, C.

for science and technology development are considered important driving forces and government's policy instruments such as direct funding and tax incentives is well documented, but implementation should be clearly lined up through an integrated policy system whereby, the science and technology institutions should be interlinked with the industrial $R \& D$ institutions as in the case of Economic Development Board (EDB) in Singapore and Ministry of International Trade and Industry (MITI) in Japan.

\section{FUTURE WORK}

While this paper focused on China's solar and wind industry, it can be extended to other industries that are playing similar roles for innovation and indigenization. Therefore comparative studies on similarities and disparities across different industries and products and technologies can be a focus of future studies.

As service innovation becomes important in emerging economies, the present framework's applicability can be investigated in the context of moving from an industrial to an information society.

Tacit knowledge quantification through survey methods can be pursued to quantify the assimilation capacity more accurately.

The present framework study can be extended to developing and developed nations to contrast and understand the effect of government policies, firm level technology strategies, market, industries and domestic know-how on the new industry growth.

\section{REFERENCES}

APERC (2009) Understanding Energy in China Geographies of Energy Efficiency, Tokyo.

Bogaert, B. (2010) Renewable Energy in China: An Analysis of Policy Instruments, Master thesis.

Buijs, B. (2011) 'Why china matters', in Sioshansi, F.P. (Eds), Energy Sustainability and the Environment: Technology, Incentives and Behavior, Elsevier, pp. 445-477.

Buijs, B. (2012) 'China and the Future of New Energy Technologies', Clingendael International Energy Programme (CIEP) (online) (cited 6 March 2013) Available from <URL:http://www.clingendael. $\mathrm{nl}>$

Chandler, J., (2009) 'Trendy Solutions: Why do states adopt Sustainable Energy Portfolio Standards', Energy Policy 37:8, pp. 3274-81. http://dx.doi.org/10.1016/j.enpol.2009.04.032.

Cheung, K. (2011) 'Integeration of Renewables: Status and Challenges in China' International Energy Agency, Paris, (online) (cited 6 March 2013) Available from <URL:http://www.iea.org>

China statistical data (2011) (online) (cited 6 March 2013) Available from <URL:http://www.stats.gov. $\mathrm{cn} / \mathrm{tjjj} / \mathrm{ndsj} / 2011>$

Chow, G. C. (2007) China's Economic Transformation $2^{\text {nd }}$ ed, Oxford, Blackwell Publishing Co. Chapter 10.

Connor, P.M. (2004) 'Renewable Electricity in the United Kingdom: Developing Policy in an Evolving Electricity Market', in De Lovinfosse I. and Louvain F. (eds.) Renewable Electricity Policies in Europe: Tradable Green Certificates in Competitive Markets, Presses Universitaires de Louvain, pp. 243-300.

Earth Policy Institute (2012) (online) (cited 6 March 2013) Available from <URL:http://www.earthpolicy.org>

EIA (2013) (online) (cited 6 March 2013) Available from <URL: http://www.eia.gov/todayinenergy> 
ERI (2009), The realization of energy conservation objective of '11th Five-year' in China: strategy and implementation, Beijing: Guangming Daily Publishing House.

Est, V. R. (1999) Winds of Change: A Comparative Study of the Politics of Wind Energy Innovation in California and Denmark, Utrecht, International Books.

Fas (2013) (online) (cited 6 March 2013) Available from <URL:http://www.fas.org/sgp/crs/row/R41919. pdf $>$.

Feinberg, S. and Majumdar,S. (2001) 'Technology Spillovers from FDI in the Indian Pharmaceutical Industry' Journal of International Business Studies, 32:3, pp. 421-438. http://dx.doi.org/10.1057/ palgrave.jibs.8490975.

Frost, T.S. (2001) 'The geographic sources of foreign subsidiaries' innovations', Strategic Management Journal, 22:2, pp. 101-123. http://dx.doi.org/10.1002/1097-0266(200101)22:2<101::AID-SMJ155>3.0.CO;2-G.

Frost (2010) Economic 360 for China: Growth Prospects and Emerging Opportunities in the Manufacturing Industry, Report no. 4726-90.

GWEC (2012) (online) (cited 6 March 2013) Available from <URL:http://www.gwec.net>

IEA (2013) (online) (cited 6 March 2013) Available from <URL: http://www.iea.org/media/etp/ Tracking_Clean_Energy_Progress.pdf>

James, Q. (2011) 'China continues to lead 'wind attractiveness' index '(online) (cited 6 March 2013) Available from <URL:http://www.windpowermonthly.com/news/1072238/China-continueslead-wind-attractiveness-index/ accessed on 6/3/2013.

Jacobsson, S., and Johnson, A. (2000) 'The diffusion of renewable energy technology: an analytical framework and key issues for research', Energy Policy, 28:9, pp. 625-640. http://dx.doi.org/ 10.1016/ S0301-4215(00)00041-0.

Johnson, A. and Jacobsson, S. (2000) 'Inducement and Blocking Mechanisms in the Development of a New Industry' in Coombs, R., Green, K., Walsh, V. and Richards, A. (eds) Technology and the Market: Demand, Users and Innovation, Cheltenham and Northampton, Massachusetts, EdwardElgar, pp.89-111.

Kahrl, F., and Holst, D. R. (2009) 'Growth and structural change in China's energy economy', Energy, $34: 7$, pp. $1-10$.

Kan, S. (2009) China energy development report 2009: Chinese photovoltaic market and industry outlook, IEEJ.

KPMG (2011) 'China's 12th five year energy policy' KPMG.

Krugman, P., (1991) Geography and trade, Cambridge, MA, MIT Press.

Leggett, J. A., (2011) China's Greenhouse Gas Emissions and Mitigation Policies Congressional Research Service, Report 7-5700, www.crs.gov, R41919.

Lewis, J., and Wiser R.H. (2007) 'Fostering a renewable energy technology industry: comparison of wind industry policy support mechanisms', Energy Policy, 35:3, pp. 1844-1857.

Li, J. (2012) China wind energy outlook, Global wind energy council (GWEC).

Lin, J. (2005) Trends in energy efficiency investments in China and the US, LBNL Report, Lawrence Berkeley National Laboratory, Berkeley, CA. LBNL-57691.

Lin, J. (2007) 'Energy conservation investments: A comparison between China and the US', Energy Policy, 35:2, pp. 916-924. http://dx.doi.org/ 10.1016/j.enpol.2006.01.024.

Lorenzen M. (2002) 'Ties, Trust, and Trade, Elements of a Theory of coordination in Industrial Clusters', International Studies of Management \& Organization, 31:4, pp. 14-34.

Lorenzen, M., and Mahnke, V. (2002) Global strategy and the acquisition of local knowledge: how MNC enter knowledge systems, Copenhagen Business School, Copenhagen.

Martinot, E., and Li, J. (2007) Powering China's development: The role of renewable energy, Worldwatch Special Report.

Meyer, P.S. and Ausbel,J.H. (1999) 'Carrying Capacity: A Model with Logistically Varying Limits', Technological Forecasting and Social Change, 61:3, pp. 209 -214.
Government's

Catalytic Role 
Srikanth, N.

Watanabe, C.
Nonaka, I., Toyama, R. (2003), The knowledge-creating theory revisited: knowledge creation as a synthesizing process, Knowledge Management Research \& Practice (2003) 1, 2-10. http://dx.doi. org/10.1057/palgrave.kmrp.8500001.

NREL(2009) 'Renewable Energy Policy in China: Overview', http://www.nrel.gov

NDRC (2007) 'China renewable energy development report, National Development and Reform Commission (NDRC)' Vol. 165, p. 5.

NDRC (2010), Policy published online, www.ndrc.gov.cn.

NREL (2013) (online) (cited 6 March 2013) Available from <URL:http://www.nrel.gov/docs/ fy04osti/35786.pdf>

$\operatorname{OECD}$ (2009) Xiaolan Fu(Ed.), Foreign direct investment, absorptive capacity and regional innovation capabilities: evidence from China, www.oecd.org.http//dx.doi.org/abs/10.1080/13600810701848193.

Porter, M. (1998) The competitive advantage of nations: with a new introduction, New York: Free Press.

PEW (2013) 'Pew Centr on Global Climate Change', (online) (cited 6 March 2013) Available from $<$ URL:http://www.c2es.org/docUploads/country-pledge-brief.pdf>.

Rai, S., Belle, J. P.V., and Pedersen, M. K. (2010) Technology transfer as a form of Co-Creation for Future Market Creation; issues, frames and concepts, Working Paper No. 05-2010.

REN21 (2010) 'Renewables-2010', global status report, http://ren21.net/.

Reuters (2013) (online) (cited 6 March 2013) Available from <URL: http://www.reuters.com/ article/2012/08/14/china-power-targets $>$.

Semi(2011) China PV roadmap, SEMI China PV Group.

Speed, A. P. (2009) 'China’s ongoing energy efficiency drive: Origins, progress and prospects', Energy Policy, 37:4, pp. 1331-1344. http://dx.doi.org/10.1016/j.enpol.2008.11.028

Sinton, J.E., Fridley, D.G. (2000)'What Goes Up: Recent Trends in China's Energy Consumption', Energy Policy, 28:10, pp. 671-687.

Srikanth, N., and Watanabe, C. (2012) 'Fusing East and West Leads a Way to Global Competitiveness in Emerging Economy Source of China's Conspicuous Strength in Solar Industry', Journal of Technology Management for Growing Economies, 3:2, pp. 7-53.

Tilman A., Hubert S., and Andreas S. (2008) 'Breakthrough? China's and India's Transition from Production to Innovation, World Development, 36:2, pp. 325-344. http://dx.doi.org/ 10.1016/j. enpol.2008.11.028.

UNEP (2011) Enhancing information for renewable energy technology deployment in Brazil, China and South Africa, UNEP.

Wang, X., (2006) Top-1000 Enterprises Energy Efficiency Program: policy design and implementation|| supporting documentation for the Energy Foundation's Forum on Implementing China's 2010 20-Percent Energy Efficiency Target, November 9-10.

Wang, Q. (2008) Sustainable energy development and economic policy research, Report for the Energy Foundation.

Wang, T. and Watson, J. (2009) China's energy transition - Pathways for low carbon development, Tyndall Centre for Climate Change Research.

Watanabe, C., Asgari, B. and Nagamatsu, A. (2003) 'Virtuous cycle between R\&D, functionality development and assimilation capacity for competitive strategy in Japan's high-technology industry', Technovation, 23:11, pp. 879-900. http://dx.doi.org/ 10.1016/S0166-4972(02)00041-X.

Wharton (2011) 'Renewable Energy in China: A Necessity, Not an Alternative: Knowledge@Wharton', http://knowledge.wharton.upenn.edu/article.cfm?articleid $=2214$

Worldbank (2013) (online) (cited 6 March 2013) Available from <URL:http://www.worldbank.org/ projects/P067625/china-renewable-energy-scale-up-program-cresp $>$

$\mathrm{Wu}, \mathrm{Q}$. (2011a) 'China takes grid-connected wind power to 52GW'(online) (cited 6 March 2013) Available from <URL:http://www.windpowermonthly.com/channel/ powersystemissues/ news/1142602/China-takes-grid-connected-wind-power-52GW/>

Wu, Q. (2011b) 'China to back wind industry with new policies', http://www.windpowermonthly.com/

Journal of Technology Management for Growing Economies, Volume 4, Number 1, April 2013 
article/1056010/China-back-wind-industry-new-policies

Yao, R., Lib B. and Steemersa, K. (2005) 'Energy policy and standard for built environment in China', Renewable Energy, 30:13, pp.1973-1988. http://dx.doi.org/ 10.1016/j.renene.2005.01.013.

Zhao, W. and Watanabe, C. (2008) 'A comparison of institutional systems affecting software advancement in China and India: The role of outsourcing from Japan and the United States', Technology in Society, 30:3, pp. 429-436. http://dx.doi.org/10.1016/j.techsoc.2008.04.020.

Zhang, D., Chai , Q., Zhang ,X., He , X., Yue, L., Dong , X. and Wu, S.(2012) 'Economical assessment of large-scale photovoltaic power development in China, Energy 40:1, pp. 370-375. http://dx.doi.org/ 10.1016/j.energy.2012.01.053.

Zhang, A. and Zhao, X. (2006) Efficiency Improvement and Energy Conservation in Chinas Power Industry, supporting Research commissioned as part of the Stern Review on the Economics of Climate Change July, 2006, available at: http://www.hm-treasury.gov.uk.

Narasimalu Srikanth, National University of Singapore, Singapore. Email: g0600356@nus.edu.sg.

Chihiro Watanabe, is Professor, Department of Industrial Management Tokyo

Seitoku University, Tokyo. Email: watanabe.c.pqr@gmail.com.
Government's

Catalytic Role 
Srikanth, N.

Watanabe, C.

\section{APPENDIX}

Table A1: Number of high technology firms and their gross output, total income and exports

\begin{tabular}{|c|c|c|c|c|c|}
\hline & $\begin{array}{c}\text { Number of } \\
\text { High-tech } \\
\text { firms }\end{array}$ & $\begin{array}{c}\text { Number of } \\
\text { Persons En- } \\
\text { gaged in High- } \\
\text { tech firms }\end{array}$ & $\begin{array}{c}\text { Gross Out- } \\
\text { put Value of } \\
\text { High-tech } \\
\text { firms }\end{array}$ & $\begin{array}{c}\text { Total Income } \\
\text { of High-tech } \\
\text { firms }\end{array}$ & $\begin{array}{c}\text { Exports of High- } \\
\text { tech firms }\end{array}$ \\
\cline { 2 - 6 } & Person & 10,000 Yuan & 10,000 Yuan & 10,000 US\$ \\
\hline 1999 & 17498 & 2210487 & 59435684 & 67747892 & 1190818 \\
\hline 2000 & 20796 & 2350679 & 79419851 & 92092630 & 1858175 \\
\hline 2001 & 24293 & 2761433 & 119284135 & 101167793 & 2266439 \\
\hline 2002 & 28338 & 3486686 & 129371015 & 153263685 & 3292207 \\
\hline 2003 & 32857 & 3953621 & 172574344 & 209387307 & 5101690 \\
\hline 2004 & 38565 & 4484387 & 226389344 & 274663091 & 8238168 \\
\hline 2005 & 41990 & 5211960 & 289575838 & 344156082 & 11164537 \\
\hline 2006 & 45828 & 5737003 & 358989390 & 433199030 & 13608826 \\
\hline 2007 & 48472 & 6502370 & 443769460 & 549251627 & 17281217 \\
\hline 2008 & 52632 & 7165307 & 526846717 & 659856923 & 20152382 \\
\hline 2009 & 53692 & 8153213 & 611513927 & 787069413 & 20072181 \\
\hline 2010 & 51764 & 8590060 & 757502707 & 971809299 & 24763404 \\
\hline
\end{tabular}

Source: China Statistical Data (2012).

Table A2: Scientific Research Institution and Enterprises Growth

\begin{tabular}{|c|c|c|c|}
\hline Year & $\begin{array}{c}\text { Scientific Research and } \\
\text { Development Institu- } \\
\text { tions }^{a}\end{array}$ & $\begin{array}{c}\text { Higher Education } \\
\text { institutions }\end{array}$ & $\begin{array}{c}\text { Large and Medium-sized } \\
\text { Industrial Enterprises }^{c}\end{array}$ \\
\hline 1995 & 146.4 & 42.3 & 141.7 \\
\hline 1996 & 172.9 & 47.8 & 160.5 \\
\hline 1997 & 206.4 & 57.7 & 188.3 \\
\hline 1998 & 234.3 & 57.3 & 197.1 \\
\hline 1999 & 260.5 & 63.5 & 249.9 \\
\hline 2000 & 258 & 76.7 & 353.4 \\
\hline 2001 & 288.5 & 102.4 & 442.3 \\
\hline 2002 & 351.3 & 130.5 & 560.2 \\
\hline 2003 & 399 & 162.3 & 720.8 \\
\hline
\end{tabular}

Journal of Technology Management for Growing Economies, Volume 4, Number 1, April 2013 


\begin{tabular}{|c|c|c|c|}
\hline Year & $\begin{array}{c}\text { Scientific Research and } \\
\text { Development Institu- } \\
\text { tions }^{a}\end{array}$ & $\begin{array}{c}\text { Higher Education } \\
\text { institutions }^{b}\end{array}$ & $\begin{array}{c}\text { Large and Medium-sized } \\
\text { Industrial Enterprises }^{c}\end{array}$ \\
\hline 2004 & 431.7 & 200.9 & 954.5 \\
\hline 2005 & 513.1 & 242.3 & 1250.3 \\
\hline 2006 & 567.3 & 276.8 & 2112.5 \\
\hline 2007 & 687.9 & 314.7 & 2681.3 \\
\hline 2008 & 811.2 & 390.1 & 3211.6 \\
\hline 2009 & 996 & 456.2 & 4015.4 \\
\hline 2010 & 1186.4 & 597.3 & \\
\hline
\end{tabular}

Government's

Catalytic Role

Source: China Statistical Data (2012).

$a, b, c$ the number indicate in units of 10,000 person.

Table A3: Health pipeline of raw material to finished products (1998-

2012)

\begin{tabular}{|c|c|c|c|c|c|c|c|c|c|c|}
\hline Year & $\begin{array}{c}\text { Total Pro- } \\
\text { duction of } \\
\text { Energy }\end{array}$ & Coal & $\begin{array}{c}\text { Crude } \\
\text { Iron } \\
\text { Ore }\end{array}$ & $\begin{array}{c}\text { Rolled } \\
\text { Steel }\end{array}$ & $\begin{array}{c}\text { Alu- } \\
\text { mi- } \\
\text { num } \\
\text { Oxide }\end{array}$ & $\begin{array}{c}\text { Alumi- } \\
\text { num } \\
\text { Prod- } \\
\text { ucts }\end{array}$ & $\begin{array}{c}\text { Elec- } \\
\text { tricity }\end{array}$ & $\begin{array}{c}\text { Ther- } \\
\text { mal } \\
\text { Power }\end{array}$ & Hydro & $\begin{array}{c}\text { Power } \\
\text { power } \\
\text { Equipment }\end{array}$ \\
\hline 98 & 122390 & 123555 & 20554 & 10508 & 334 & 147 & 11388 & 9290 & 1949 & 1930 \\
\hline 99 & 104139 & 97781 & 20934 & 11957 & 384 & 174 & 11978 & 9854 & 1969 & 1469 \\
\hline 00 & 98834 & 88010 & 22395 & 13146 & 432 & 217 & 13256 & 10867 & 2212 & 1249 \\
\hline 01 & 106185 & 96418 & 21701 & 15745 & 475 & 229 & 14333 & 11768 & 2380 & 1339 \\
\hline 02 & 118317 & 111293 & 23143 & 19218 & 548 & 276 & 16024 & 13288 & 2465 & 2121 \\
\hline 03 & 134992 & 132670 & 26108 & 23582 & 619 & 363 & 18462 & 15421 & 2593 & 3701 \\
\hline 04 & 158618 & 160611 & 31010 & 29739 & 702 & 448 & 21302 & 17702 & 3065 & 7138 \\
\hline 05 & 178640 & 182424 & 42049 & 37117 & 861 & 594 & 24146 & 19857 & 3644 & 9640 \\
\hline 06 & 198187 & 206599 & 58817 & 46685 & 1324 & 834 & 27557 & 23189 & 3783 & 11882 \\
\hline 07 & 218698 & 229468 & 70707 & 56461 & 1951 & 1240 & 32087 & 27013 & 4343 & 13180 \\
\hline 08 & 248000 & 262183 & 82401 & 58177 & 2279 & 1477 & 34047 & 27857 & 5277 & 13343 \\
\hline 09 & & 296477 & 88017 & 69244 & 2383 & 1770 & 29814 & 5545 & & 4394 \\
\hline 10 & & 20301 & 6807 & 3153 & 1067 & 336382 & 6622 & & & 12993 \\
\hline 11 & & 20365 & 8122 & 3424 & 1111 & 413329 & 6108 & & & 14739 \\
\hline
\end{tabular}

Source: World Bank Data (2012). 
Srikanth, N.

Watanabe, C.

\section{APPENDIX B1}

\section{China's Renewable Energy Policies - Laws, Instruments and Pro- grammes}

China energy policy challenges are largely framed by national socioeconomic policy goals; climate policy competes economic development policy particularly climate and environment measures (Speed, 2009). Renewable energy was recognized as a good solution worldwide to global warming and emission reduction but there is no reference to climate change or GHG emissions in the "Renewable Energy Law of People Republic of China" that became effective from 1st January 2006 (Wang and Watson, 2009). Table A1 in Appendix lists the prominent renewable laws and regulations of China.

\section{China 12th Five Year Plan}

The national five year plan for Economic and Social Development (FYP) is a key strategic document of the Chinese government and is seen as a crucial document that have directed policy since the establishment of People's Republic in 1949. It sets the development priorities and basic governmental objectives of the country in the upcoming five year period. In 1980s, the FYP focused on growing attentiveness to energy concerns (Yao et al., 2005). In 6th FYP (1981 to 1985) it focused on 10\% of energy supply investment into energy conservation projects and was continued to 7 th FYP and the percentage reduced to $8 \%$. From 2001 to 2005, the Agenda 21 was implemented to the 9th FYP for sustainable development and a plan for Renewable Energy Development was introduced, to offer recommendations for adoption of renewable energy. In the 11th five year plan (2006-2010) directed by the scientific development perspective, China set a target to produce $15 \%$ primary energy from renewable sources (including hydropower) by 2020, and up from 7.5\% in 2005 (NDRC, $2007 b$ ). For the electricity sector, the target is $20 \%$ by year 2020 which includes $20 \mathrm{GW}$ from wind power, $30 \mathrm{GW}$ from biomass, particularly in wind and solar power and $300 \mathrm{GW}$ from hydropower. This set an ambitious path to adopt renewables.

China's national people congress approved a new national development strategy for the next five years (2011 to 2015) in March 2011 (KPMG, 2011). The 12th FYP designates seven strategic emerging industries (SEI) as the drivers for China's future economic development from low-end manufacturing to higher-value industries and creating sustainable growth. Clean energy technology; high-end equipment manufacturing; alternative energy; new materials; and clean energy vehicles are some of the key focus and aligns with sustainable growth. However, the $12^{\text {th }}$ FYP does not specify any preferred financing,

Journal of Technology Management for Growing Economies, Volume 4, Number 1, April 2013 
tax breaks, subsidized electricity and utility fees, free or subsidized land, etc. Chinese government support for at least one of these industries has been successful in the past. During the 11th FYP, China designated clean energy technology (solar, wind, bio, and nuclear energy) for government support, spending approximately 2 trillion RMB (US\$ 309 billion) on energy efficiency and environmental protection measures. In the $12^{\text {th }}$ FYP the key focus was on clean energy, energy conservation, and clean energy cars as three key investment areas (among seven special sectors) identified in china's. Among the various renewable energy, China bets on hydro power and not much on nuclear power after the Japan nuclear accident in 2011. It motivates expansion of wind, solar and biomass particularly wind and solar as core in its environmental efforts as follows.

1. Wind power generation: with the continuation of strong policies supporting the development of wind power, the sector needs to move from rapid expansion to a stage of healthy development. By 2015, annual generation of wind power will reach $190 \mathrm{TWh}$, which is more than the energy produced by 60 million tons of standard coal.

2. Solar energy generation: the sector needs to achieve fast development and expand installed capacity. Development goals are 5 to $10 \mathrm{GW}$ by 2015 .

The China's big five power generation groups (China Huaneng, China Guodian, China Datang, China Huadian, and China power investment) are actively looking for foreign direct investments and are engaged in adopting new technologies such as smart grid development which is an effort to improve energy efficiency through the support of foreign players (example, Siemens and $\mathrm{ABB}$ ) and thus can co-evolve new equipment industries in smart meter supply.

\section{Policy Development for Wind and Solar}

China's renewable energy policies have not been seen significant inducement to a renewable energy, but it clearly played a catalytic role in the production capability development in wind and solar industry and favoured domestic market development in the wind energy and export market in the solar industry as described in the following section.

\section{China's Wind Energy Policy}

In the 1980s, efforts by Wang Wenqi to create China's wind power capital in Dabacheng putting 300 wind turbines to support irrigation works. Today, it generates $500 \mathrm{MW}$ and not the largest capacity it had the pioneering effort that comprised of domestic and foreign turbines. In 2003, to increase wind power

Journal of Technology Management for Growing Economies, Volume 4, Number 1, April 2013
Government's

Catalytic Role 
Srikanth, N.

Watanabe, C.

sources the China government shifted to a market oriented policy to address commercial wind farms. The generated wind power was supplied to the state grid through bidding process. With this a stable domestic market evolved.

Some of the supply side policies include heavy investment for leveraging external know-how through technology leasing and joint ventures. Applied regional feed in tariffs to take the variation in the grid availability and transmission loses between the generated location and demand location. Promotions loans and subsidies to domestic firms in the production chain and insistence of up to $90 \%$ domestic parts requirement in all domestic installed turbines (Lewis and Wiser, 2007).

Demand side policies include China's public tendering for concession wind power projects. To increase the wind turbine installations, the government adopted a market oriented policy for wind power concession projects in 2003 to motivate power saleable wind farms to sell wind electricity that was traded by a bidding process with the provincial grid companies and were managed by National Development and Reform Commission which resulted in a stable domestic market evolution. For example, China's promotional feed in tariffs in 2006 as shown in Table B1 compared to fossil fuels and to address the disparity between regions it introduced varying feed in tariff as shown in table B2 which helped the adoption of wind energy optimally in different regions based on their wind resource, grid availability, local demand, transmission loss to the point of usage, etc.

Table B1: Feed in tariff of wind energy generated power into state grids

\begin{tabular}{|l|c|c|c|}
\hline Province & $\begin{array}{c}\text { Fossil based cost of } \\
\text { energy } \\
\text { (Euro-cent/kWh) }\end{array}$ & $\begin{array}{c}\text { Feed in tariff } \\
\text { (Euro-cent/ } \\
\mathbf{k W h} \text { ) }\end{array}$ & $\begin{array}{c}\text { Percentage differ- } \\
\text { ence (\%) }\end{array}$ \\
\hline Hebei & 2.81 & 9.59 & 241 \\
\hline Inner Mongolia & 1.94 & 6.01 & 210 \\
\hline Xinjiang & 1.74 & 5.23 & 200 \\
\hline Shandong & 3.29 & 7.75 & 135 \\
\hline Liaoning & 2.91 & 8.82 & 203 \\
\hline Jilin & 2.91 & 8.72 & 200 \\
\hline Guangdong & 4.94 & 6.59 & 33 \\
\hline Zhejiang & 4.07 & 11.72 & 188 \\
\hline Fujian & 3.97 & 4.46 & 12 \\
\hline
\end{tabular}

China had clear feed in tariff variation with region as listed in Table B2, which

Journal of Technology Management for Growing Economies, Volume 4, Number 1, April 2013 
promoted the growth of larger wind farms in remote places with wind rich conditions.
Government's

Catalytic Role

Table B2: Feed in tariff for different Wind Farms in different Region

\begin{tabular}{|l|l|c|c|}
\hline \multicolumn{1}{|c|}{ Province } & \multicolumn{1}{c|}{$\begin{array}{c}\text { Name of the wind } \\
\text { farm }\end{array}$} & $\begin{array}{c}\text { capacity } \\
\text { (MW) }\end{array}$ & $\begin{array}{c}\text { Tariff (RMB/ } \\
\text { KWh) }\end{array}$ \\
\hline Jiang Su & Ru Dong & 100 & 0.4365 \\
\hline Guang Dong & Hui Lai & 100 & 0.5013 \\
\hline Inner Mongolia (Western) & Huitengxile & 100 & 0.382 \\
\hline Inner Mongolia (Western) & Huitengxile & 100 & 0.382 \\
\hline Jilin & Tongyu & 200 & 0.509 \\
\hline Jilin & Tongyu & 200 & 0.509 \\
\hline Jiang Su & Ru Dong & 100 & 0.519 \\
\hline Jiang Su & Ru Dong & 200 & 0.4877 \\
\hline Jiang Su & Dafeng & 200 & 0.4877 \\
\hline Gansu & Anxi & 100 & 0.4616 \\
\hline Inner Mongolia (Western) & Ximeng Huitengliang & 300 & 0.42 \\
\hline Inner Mongolia (Western) & Ximeng Huitengliang & 300 & 0.42 \\
\hline Inner Mongolia (Western) & Bayin & 200 & 0.4656 \\
\hline Hebei & Zhangbei Danjing & 200 & 0.5006 \\
\hline Inner Mongolia (Weastern) & Wulan Yili & 300 & 0.468 \\
\hline Inner Mongolia (Eestern) & tongliao beiqing & 300 & 0.5216 \\
\hline
\end{tabular}

Source: GWEC China wind tariffs (2011).

\section{China's solar energy policy}

The five year plan (2011-2015) for solar industry developed by Ministry of Industry and Information Technology was released in Feb 2012 chiefly focusing on supply and demand side (Semi, 2012). Following are some key aspects:

1. Reduce the cost of domestic solar power to 0.8 Yuan (about US \$0.13) per kwh by 2015 and 0.6 Yuan (about US $\$ 0.10$ ) by 2020 ,

2. The cost of solar panels in China will drop to 7000 Yuan (about US\$1100) per kw by 2015 and 5000 Yuan (about US\$ 800) per kw by 2020,

3. The plan requires China's leading polysilicon manufacturers to reach a 50000 ton annual production capacity (per firm) and leading solar panel makers to reach $5 \mathrm{GW}$ (annually per firm) by 2015 ,

4. China will further help solar companies increase their annual sales, with atleast one firm reaching 100 billion Yuan (about US\$ 16 billion) in sales 
Srikanth, N.

Watanabe, C. and 3 to 5 firms reaching 50 billion Yuan (about US\$ 8 billion) in sales by 2015 .

5. Increase the conversion efficiency of monocrystalline silicon solar cell to 21 percent, polysilicon cell to 19 percent and amorphous silicon cell to 12 percent by 2015 .

6. Eighty percent of solar equipment and auxiliary materials will be produced domestically,

7. Thereby it aims at and having a minimum installed capacity target of 5 GW by 2015 and $20-30$ GW by 2020 such that these large scale capacities is being planned to be placed in deserts.

China's central government has launched a number of demand side policies to promote PV power installation (Zhang et al., 2012):

1. Before 2009: PV installation depended on government financed projects "Tibet Non-electricity countries electrification project", "China Brightness Project", "Tibet Ali PV Plan", "China Rural Township Electrification Program" and "Non-electricity Areas Electrification Program", and the cumulative installation is small.

2. 2009: subsidies for "Golden Sun demonstration Program".

3. 2009 and 2010: Two series of concession projects.

4. As per 2010 , the total installation is only $800 \mathrm{MW}$, which equates to $10 \%$ of annual production of PV cells (Semi, 2011).

5. 2009 to 2011: "Solar PV for building program" for greater than $50 \mathrm{KW}$.

Concession project has been recognized as an efficient and effective approach to figure out the real cost of new power generation technology and bring down the cost through demonstration borrowing the successful experience of wind power development. Therefore, two series of concession projects with total capacity of 290 MW were taken off in 2009 and 2010.

"Golden Sun Demonstration Program" is also a good example in shedding light on LSPV. In 2009, China's Ministry of Finance, Ministry of Science and Technology and the National Energy Administration of the National Development and Reform Commission jointly announced the program which provides upfront subsidies for qualified demonstrative PV projects from year 2009 to 2011. The subsidy will cover 50\% of total cost for on-grid systems and $70 \%$ of total cost for offgrid systems. Compared to the first national subsidy program - "Solar PV for Buildings Program" with minimum system size of $50 \mathrm{~kW}$, the required system size increased to $300 \mathrm{~kW}$.

Journal of Technology Management for Growing Economies, Volume 4, Number 1, April 2013 